\title{
Some Observations on the Tuber of Phylloglossum.
}

$\mathrm{BY}$

\section{T. G. B. OSBORN.}

With Plate XXVIII and forty.three Figures in the Text.

W HEN, towards the end of the growing season I9I7, the opportunity offered to study Phylloglossum Drummondii in the field near Adelaide, it was felt that some observations of interest might be made upon the ecology of the plant, with special reference to the behaviour of the tuber as an organ of perennation. The scope of the inquiry was unexpectedly extended by the discovery that accidentally damaged or detached leaves might themselves form new tubers as they lay upon the soil near naturally growing plants: A series of observations was therefore made during the growing season (May to October) 1918, the results of which are also given here. Without wishing at this stage to reopen a discussion as to the morphology of Phylloglossum Drummondii, it is felt that the facts now presented throw some light on the nature of the tuber that is of importance in considering its morphology.

\section{Field Observations on Phylloglossum.}

The external morphology of Phylloglossum has been so-many times described that a further account might be deemed superfluous. In the present paper, the tuber, formed the previous season, from which arise the stem, leaves, roots, and strobilus (should one be produced), and which is consequently in process of exhaustion, is termed the 'current tuber'.1

The term 'old tuber' is restricted to those of previous years, which may be found in the soil beside growing plants. ${ }^{2}$ These may throw a light upon the past history of the plant near which they are found.

\section{On the Depth of Tuber Formation-Descriptive.}

On examining any large number of plants of Phylloglossum collected towards the end of their growing season, the two tubers are usually observed side by side at about the same depth below the ground-level. Unlike the

1 Wernham, H. F. (1910) : Ann. Bot., xxiv, p. 335.

2 Thomas, A. P. W. (1902): Proc. Roy. Soc., London, lxix, p. 288.

[Annals of Botany, Vol. XXXIII. No. CXXXII: October, rg19.] 
perennating organs of many geophytes, these two structures, products of successive seasons' activities, are not directly connected. The new tuber is linked to the current one only by its stalk, which is given off from the stem of the plant usually some distance above the current tuber. Clearly, then, the new tuber is produced sunken in the soil because of the downward growth of its stalk. Whilst the growth is usually of such an amount.as to cause the two tubers to lie side by. side, this is by no means always the case.

Not infrequently plants are found in the condition shown in Text-fig. $x$. Here the new tuber is produced at the end of a relatively short stalk, and is

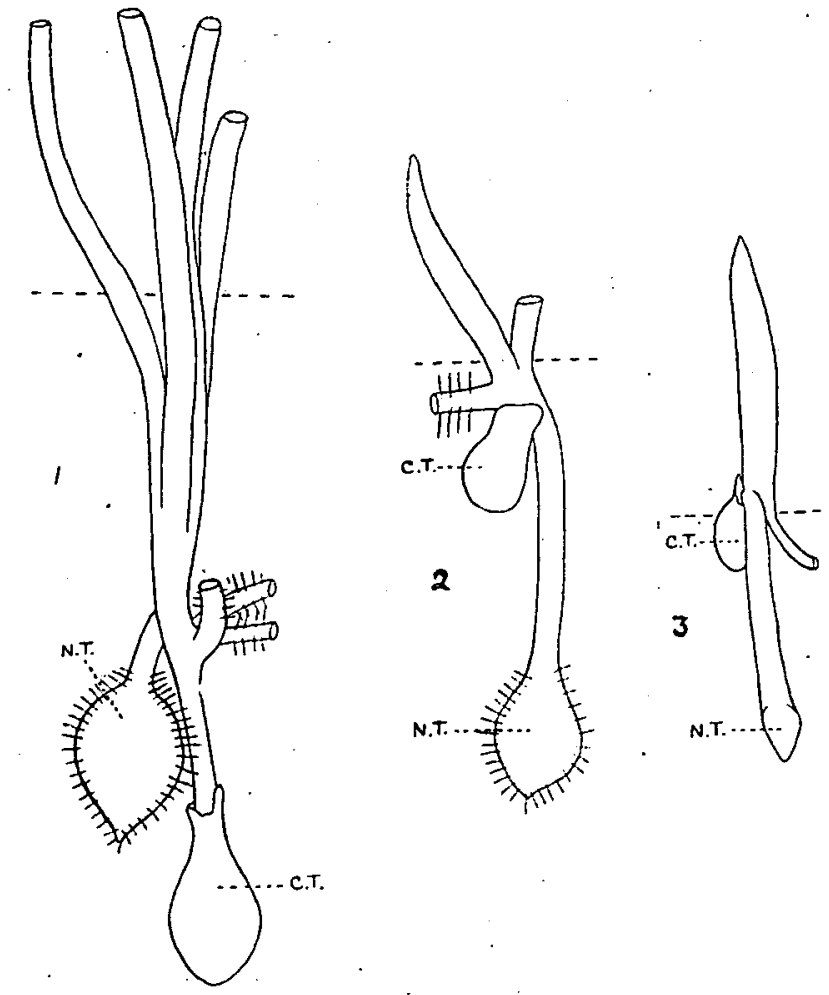

Text-Fig. i. Four-leaved sterile plant showing current tuber buried about $18 \mathrm{~mm}$. New tuber formed on short stalk at shallower depth (Oct. 1917). $\times 3 \frac{1}{2}$.

TExr-fig. 2. Two-leaved sterile plant with current tuber $4 \mathrm{~mm}$. below ground-level. New tuber formed on long stalk. Sunken about $11 \mathrm{~mm}$. (Oct. I917). $\times 3 \frac{1}{2}$.

TExT-FIG. 3. Single-leaved plant with current tuber partially exposed. New taber as yet scarcely swollen, but sunken to $7 \mathrm{~mm}$. (Sept. 14,1918 ). $\times 3 \frac{1}{2}$.

thus placed vertically in the soil several millimetres nearer the surface than the current tuber. -

Or again, specimens may be found in which the current tuber lies just below the surface of the soil (Text-fig. 2) or even partially exposed (Textfig. 3). Here the new tuber is produced at the end of a relatively long 
stalk; hence it may be buried in the soil two or three times its own length deeper than the current tuber. ${ }^{1}$

The examination of any considerable number of plants collected at one time from the same locality shows that the depth at which the new tuber is formed in the soil in relation to ground-level is not a matter of chance, but is the result of definite growth of the plant producing it. If, for any reason, the current tuber is buried by deposition of more soil above it, the burial is compensated for by the development of a short stalk bearing the new tuber. Conversely, if, by removal of surface soil, the current tuber is brought near to the surface, the new tuber is sunken to a greater depth.

There are two sets of climatic conditions that tend to produce an alteration of the ground-level in the area where Phylloglossum has been studied near Adelaide. ${ }^{2}$ In the wet season (April to October) or during periods of heavy precipitation, which occasionally occur in the summer, there is, .owing to local irregularities in the ground, a flow of water over the surface in many places. This causes a removal of soil from some areas and its consequent deposition over others. Since the ground over the greater part of the area is almost flat, the amount of change in level is slight; but very slight changes have a considerable effect on such a minute plant.

On the other hand, during the dry season, when for weeks together the surface layers of the soil are desiccated, atmospheric denudation causes similar slight changes in ground-level. Such variations may not exceed a few millimetres rise or fall, but they influence to a marked degree a plant whose total length from tip of leaf to base of tuber may be less than $3 \mathrm{~cm}$. and the optimum depth for whose tuber lies between Io and $12 \mathrm{~mm}$.

\section{On the Depth of Tuber Formation-Statistical.}

In order to gain a clear idea of the depths at which the tubers of a number of Phylloglossum plants taken from any area may occur, three typical groups of plants were selected in October (i. e. near the close of the growing season) and a sod of soil some ro $\mathrm{cm}$. square cut from each. The three sods were carefully removed to the laboratory, where every plant was dissected out. Two measurements were then made upon each plant, viz. the maximum depths of the current and: new tubers. The points of imeasurement selected were the ground-level (usually. sharply defined by the development of chlorophyll) and the deepest point of the tuber. It was found desirable to include the length of the tuber in the measurement in order to avoid minus quantities when the tuber was partly exposed, and also because the distal end of the tuber is well defined while the proximal end passes gradually into the stalk.

\footnotetext{
1 Bertrand's figure of Phylloglossum reproduced in Campbell, D. H.,;Mosses and Ferns, p. 501 , Fig. 290 A, shows this condition, but to a less extreme degree than either of the plants figured above. I regret $I$ have not been able to consult a copy of Bertrand's memoir in Australia.

2 Osborn, T. G. B..(1918) : Trans. Roy. Soc., S. Aus., xlii, p. 7:" 
In all 186 plants were obtained from the 300 sq. $\mathrm{cm}$. (approx.) of soil. The figures obtained are surprising in the close way they agree with the result that field observations had indicated.

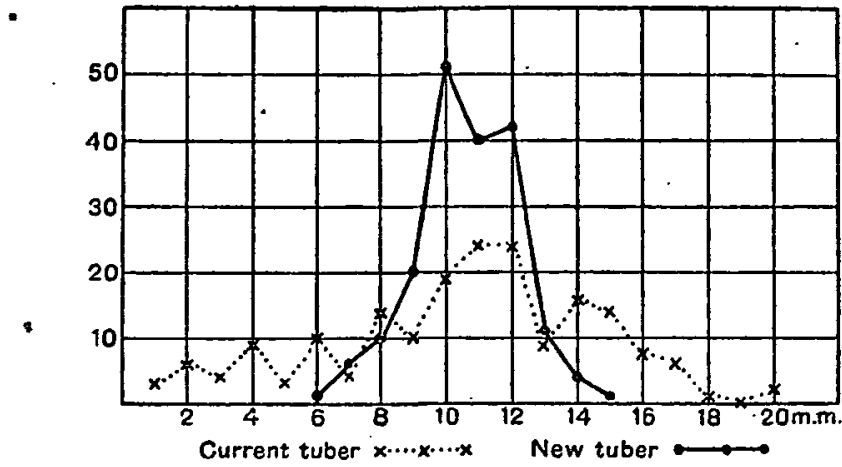

TEXT-FIG. 4. Graph showing variation in depth of current and new tubers on I 86 plants collected from (approx.) 300 sq. cm. soil (Oct. I917).

Phylloglossum Drummondii, 186 plants from $300 \mathrm{sq} . \mathrm{cm}$. soil.

$\begin{array}{ccl}\text { Depth of tubers in } \mathrm{mm} . & \text { Current. } & \text { Nezu. } \\ \text { Average } & 10.5 & 10.6 \\ \text { Minimum } & 1 & 6 \\ \text { Maximum } & 20 & 15 \\ \text { Mean } & 10.5 & 10.5\end{array}$

The graphic representation of the results shown in Text-fig. 4 is specially interesting. The depths of the current tubers give a very irregular flat curve with the mode at $11.5 \mathrm{~mm}$. but with secondary maxima at $8 \mathrm{~mm}$. and $14 \mathrm{~mm}$. The depths of the new tubers, on the other hand, give an almost symmetrical curve about the mode at $10 \mathrm{~mm}$. The curve, moreover, is a steep one, over 80 per cent. of the individuals falling between $9 \mathrm{~mm}$. and $12 \mathrm{~mm}$.

\section{On the Direction of Growth by the New Tuber.}

At this stage it may be well to record an observation that bears on the factors determining the direction of growth by the new tuber. The new tuber has always been found upright in the soil, its long axis being vertical. This suggests that gravity is the determining factor in the direction of growth. In compensating for excessive depth at which the current tuber may have been buried, the new tuber never grows erect or even horizontally. A shallower depth is attained merely by the slight amount of elongation made by the new tuber stalk. The flexure made by this stalk is always sharply downwards. Since the point upon the stem from which the new tuber arises is apparently determined by morphological reasons (this is certainly so in the case of sterile plants), ${ }^{1}$ it may happen that when

'Bower, F. O. (1886): Phil. Trans., clrxvi, p. 669. 
the current tuber is very deeply sunken the plant cannot in one season adjust the new tuber to the normal or average depth. Thus two plants having the current tuber buried to $20 \mathrm{~mm}$. produced their new tubers at $15 \mathrm{~mm}$. and $\mathrm{I}_{4} \mathrm{~mm}$. respectively. Assuming no change occurred in the ground-level, the new tubers of the ensuing season would also be on short stalks; thus two, or even three, seasons might pass before the average depth was established.

An example of the influence of gravity upon the direction of growth of the new tuber stalk was furnished by a plant growing in the laboratory. In cutting a sod of soil, to be kept moist under a bell-glass for experimental purposes, the trowel accidentally exposed, without damaging, the new tuber stalk of a five-leaved sterile plant. The stalk at that date (July 2I, I9I8) was still, short, the apex unswollen. It continued to grow, exposed to light, descending vertically through $19 \mathrm{~mm}$. before it buried itself in the silt at the bottom of the dish (October 2r, I9r8). The growth here was clearly geotropic. Light had no influence upon it, for the stalk, though it developed chlorophyll throughout its whole exposed surface, made no phototropic response. This observation is of some importance when considering the behaviour of tubers produced by detached leaves.

\section{On the Rate of Development of Phylloglossum in Successive Seasons.}

The sporeling of $P / h y l l o g l o s s u m$ described by Thomas ${ }^{1}$ is single leaved and rootless ${ }^{2}$ in the first season of its growth. The number of leaves may be assumed to increase from year to year as successive seasons' activities allow more starch to accumulate in the new tubers. ${ }^{3}$ Thomas records that the further development of the sporophyte appears to be slow. 'In many cases the plant comes up a second and third year with only a single leaf.' This he determined by carefully dissecting plants from the soil, and so finding the remains of former years' tubers and roots. ${ }^{4}$

After a little practice it was found possible to remove the remains of the old tubers, together with the plant to which they belonged, without disturbing their relative position one to the other. Text-fig. 5 shows a. single-leaved plant collected about a month after the first winter rains. The root is hardly developed and no new tuber is visible at this date, but, in addition to the current tuber, the decaying remains of the tubers formed

1 Loc. cit., p. 288.

Sampson, K. (i916): Ann. Bot., xxx, p. 605. The sporeling described by Miss Sampson was also single leaved, but had a slender root.

3 The number of leaves in any season, of course, is not determined antil after germination of the tuber. Bower, F. O. (1886) : loc. cit., p. 667 .

1 Loc. cit., p. 288 . 
in two previous years are visible. Such a single-leaved plant is entering on at least the fourth season of its growth.

Text-figs. 6 and 7 show plants of two and three leaves respectively. In Text-fig. 6 three old tuber coats are to be seen. These lie just below the surface of the soil, the current tuber being several millimetres deeper. The. past history of this plant, as shown by its old tuber coats, affords a further example of the depth adjustment referred to above. The plant was collected July I9r 8 ; the current tuber, therefore, had been formed in the: 19J7 growing season. That year, the then current tuber, now O.T. ${ }_{1}$, lay close below the surface of the soil, so that the plant produced its. new tuber, C.T. in the figure, at the end of an elongate stalk. Evidently the

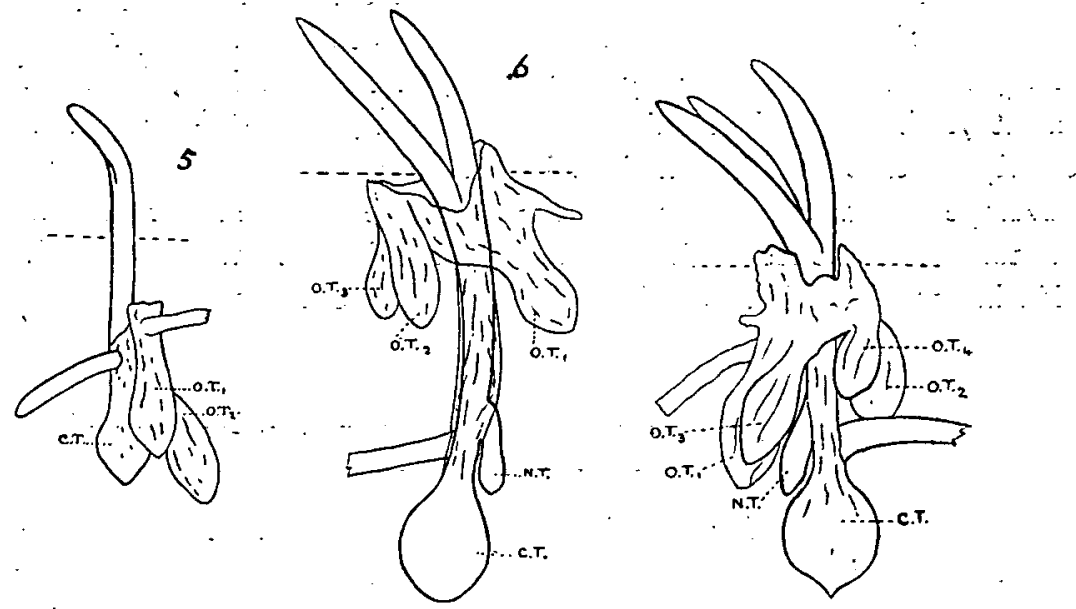

'TexT-FiG. 5. Single-leaved plant with current tuber C.l. and two old season's coats o.T. and 0.T.2. This plant is entering on the fourth scason of growth. At this date the root is short and no new tuber visible (June I 3,1918 ). $\times 3 \frac{1}{2}$.

TEXT-FIG. 6. Two-leaved plant with current tuber C.T. at I I mm. depth, new tuber $N . i$. just forming. Coats of three previous seasons' tubers $\left(\right.$ O.T.,, O.T. $_{2}$, O.T.g) are just below ground-level, showing depth adjustment in 1917 (July II, 1918 ). $\times 3 \frac{1}{2}$.

TEXT-FIG. 7. Three-leaved plant with current tuber C.T. at $9 \mathrm{~mm}$. depth. Old tuber coats (o.T., \&c.) of four previous seasons at shallower depth (July 11,1918$). \times 3 \frac{1}{2}$.

lowering of the ground-level occurred some time subsequent to the 1916 growing season, for lying at the same depth as $0 . \mathrm{T}_{\cdot_{1}}$ are $0 . \mathrm{T}_{\cdot_{2}}$ and $\mathrm{O} \mathrm{T}_{\cdot_{3}}$, tubers of two previous seasons.

Around another plant no less than four old tuber coats were found (Text-fig. 7), all lying above the current tuber, again demonstrating the burial of the perennating organ to a safe depth. This plant, though it possesses but three leaves, was entering on at least the sixth year of its growth.

Such examples illustrate Thomas's observation on the slow rate at which the sporophyte develops. They also show to a slight extent the precarious existence led by the Phylloglossum in some areas, as it seesaws 
in the ground, threatened by burial or desiccation, as a result of the edaphic and climatic conditions under which it grows. Development is by no means always a steady progress in which, through successive seasons, the tuber gradually attains a maximum size. In cases where considerable depth adjustment has to be made, or where the early onset of the dry season brings vegetation to a standstill, ${ }^{1}$ the new tuber formed may be smaller in size than that from which the plant producing it was derived.

\section{Production of Tubers by Leaves.}

\section{Field Observations 1917.}

In I9I7, when dissecting plants of Phylloglossum from the soil for the statistical investigation above, a specimen was found which at first could not be interpreted. A small green leaf-like structure was found lying in the soil (Text-fig. 8), pointed at one end, the other terminating bluntly, smooth, and rounded. When removed from the soil it was found that this blunt end had a colourless cylindrical prolongation, nearly as long as the aerial portion of the structure, descending vertically into the ground. Its apex showed a minute white spot, and resembled the apices of young tuber stalks of Phylloglossum. In the angle made by the two portions a few colourless rhizoids were developed.

When searching for similar structures the leaf shown in Text-fig. $9 \mathrm{~A}$ was found. This was obviously a detached leaf of Phylloglossum; but near its proximal end a slight swelling of adventitious tissue had developed on the side next the soil. Such a pad of adventitious tissue, which in the following pages will be termed the 'cell mass' for convenience of reference, has been invariably observed as a preliminary development in growth from detached leaves of Phylloglossum. Further search yielded two similar leaves, Text-figs. Io and I $A$, also a third, in which, however, the cell mass was better developed (Text-figs. $12 \mathrm{~A}, \mathrm{~B}$, and $\mathrm{C}$ ): This last leaf was somewhat curved and lay upon the soil with its proximal end slightly elevated. It had produced laterally, from the convex side, a cell mass about $2 \mathrm{~mm}$. long; this was swollen irregularly at the farther end and was partly embedded in the soil. The cell mass was green where exposed to the light, while from the lower side of the swollen end rhizoids were produced. From the under surface of this swelling a colourless, almost cylindrical process descended into the soil.

It now became apparent that detached leaves of Phylloglossum were capable of producing, after more or less adventitious growth resulting in a cell mass, a structure resembling the stalk of a tuber, such as the plant normally forms each growing season. The structure shown in Text-fig. 8

1 See p. $5^{\circ 8}$, for rainfall record at Belair, S. A., near which township Phylloglossum has been studied. In 1915 only 1.37 in. of rain fell during the last three months of the year. 

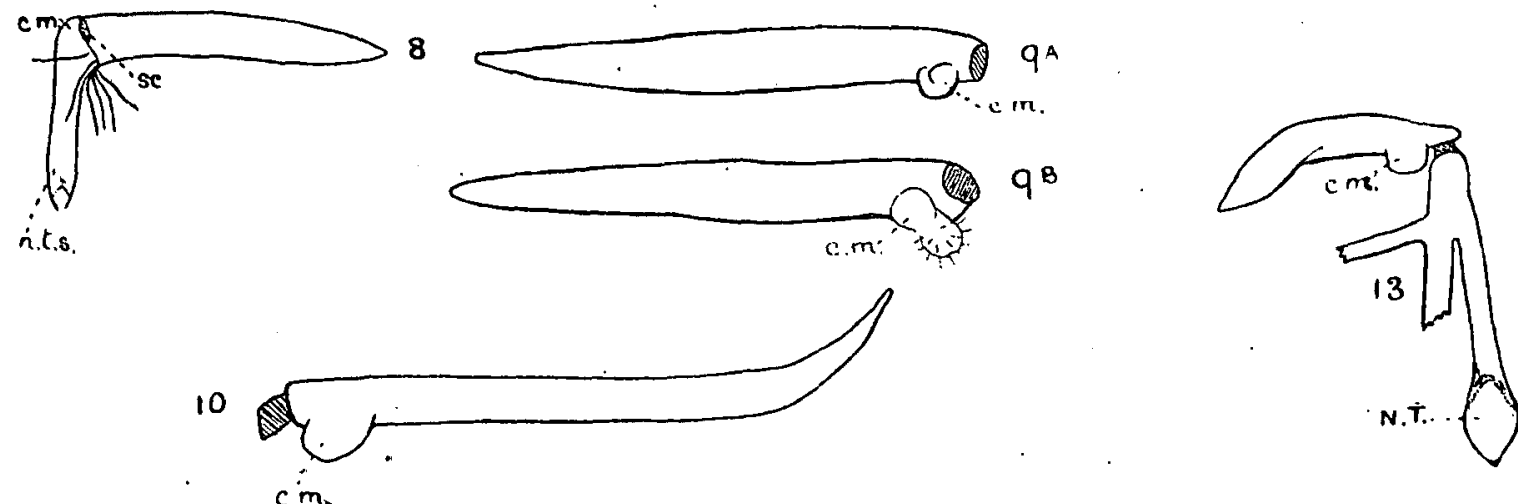

10

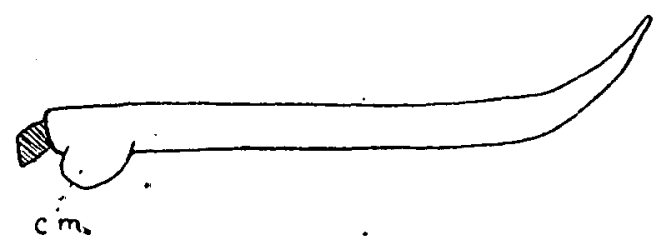

"1/A
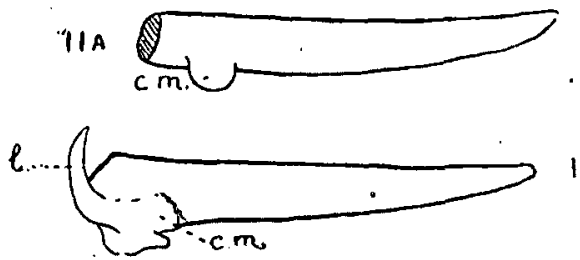

$11 \mathrm{~B}$

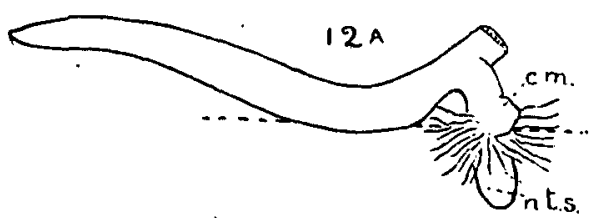

TEXT-FIGS. 8-14. Regenerating leaves collected in field (Oct. 1917). Lettering throughout : c.m. $=$ cell mass, n.t.s. $=$ new tuber stalk. Except where otherwise stated, viewed from side. All $\times 5 \frac{1}{4}$. Fig. 8. Detached leaf lying horizontally on soil showing regeneration. A stalk's minute tuber has formed from the cell mass developed at proximal end. The scar (sc.) is almost obliterated. Fig. 9 A. Leaf as collected. Fig 9 . Same after seven weeks on moist soil. Fig. I A. Leaf as collected. Fig. I $\mathrm{B}$. Same after seven weeks on moist soil. Note development of 'leaflet' $(l)$. Fig. I 2 A. Leaf with unusually large cell mass formed Same after seven weeks on moist soil. Note development of 'leaflet' (l). Fig. I $2 \mathrm{~A}$. Leaf with unusually large cell mass formed
at ground-level, also stalk with growing-point beginning to elongate. Figs. I 2 B and c. Same viewed from proximal end. Note at ground,level, also stalk with growing-point beginning to elongate. Figs. I 2 B and c. Same viewed from proximal end. Note
expansion of cell mass at ground-level, also its development from convex side of curved leaf. Fig. 13. Single-leaved plant forming adventitious cell mass on leaf above injury, also new tuber; current tuber not shown. Fig. t4. Three-lenved plant with cell mass forming from proximal end of broken leaf.
$12 c$

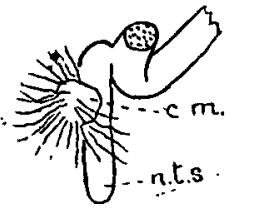

$12 \mathrm{~B}$

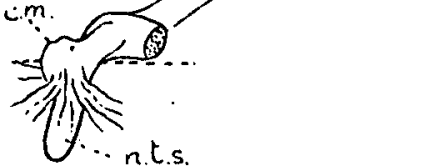

C.T.

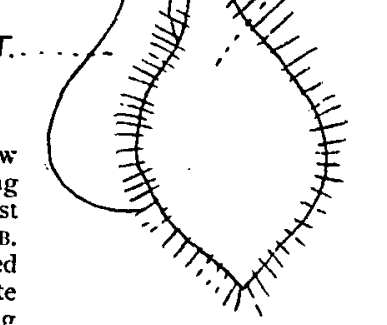


was evidently such a leaf on which the cell mass was small in size, but had almost obliterated the scar formed when the leaf was detached. This scar, somewhat exaggerated in the figure, was so minute that it was not recognized when first examining the leaf.

Two further plants of interest were found in the field that season. One, a single-leaved plant, had suffered an injury about $1 \mathrm{~mm}$. above the soil. The leaf was broken through and lay along the soil, but was not actually detached. The wounded surface had healed over, and a new tuber was forming normally (Text-fig. I3). The broken leaf, however, had not died, but was turgid and green beyond the zone of injured tissue. It had, moreover, begun to form a cell mass upon the lower surface. The second plant was a three-leaved one, one leaf of which had been broken and lay along the soil. Again the wound had healed on both sides of the injury, and the damaged leaf had developed a cell mass near to the proximal end, from the surface of which several rhizoids arose (Text-fig. I4).

The growing season for Phylloglossum was almost over in $19 \mathrm{I} 7$ when these observations were made, so that experimental work was impossible. The two leaves shown in Text-figs. $9 \mathrm{~A}$ and II A, however, were laid upon soil from the locality in which they had been found, placed in a Petri dish, and kept moist in the laboratory. After about seven weeks it became necessary to stop the experiment as the leaves were beginning to decay. That shown in Text-fig. $9 \mathrm{~A}$ had developed a further swelling, irregularly spherical, closely connected with the first (Text-fig. $9 \mathrm{~B})$. The new swelling was opaque, white, and bore short rhizoids. The other leaf (Text-fig. I I A) showed an unexpected development. No stalk-like structure had formed, but the original cell mass was considerably enlarged (Text-fig. I $1 \mathrm{~B}$ ), and a minute green leaf-like scale (l) had developed.

\section{Experimental Development, 1918.}

In 1918 five series of experiments upon the production of tubers by detached leaves were carried out in the laboratory, the results of which are here given in tabular form, and are further discussed below.

\begin{tabular}{|c|c|c|c|c|c|c|}
\hline $\begin{array}{l}\text { Series. } \\
\text { Letter. }\end{array}$ & $\begin{array}{l}\text { Date Expt. } \\
\text { started. }\end{array}$ & $\begin{array}{l}\text { No. of } \\
\text { Leaves. }\end{array}$ & $\begin{array}{l}\text { No. formed } \\
\text { single taber. }\end{array}$ & $\begin{array}{l}\text { No. formed } \\
\text { single cell } \\
\text { mass. }\end{array}$ & $\begin{array}{l}\text { No. formed } \\
\text { several cell } \\
\text { masses. }\end{array}$ & $\begin{array}{l}\text { No. died of } \\
\text { without apparent } \\
\text { growth. }\end{array}$ \\
\hline A. & 13. VI & 8 & $\mathbf{I}$ & (I) & 6 & - \\
\hline $\mathrm{B}$. & II. VII & 8 & & $i^{*}$ & 一 & - \\
\hline C. & 21. VII & 10 & $5 \dagger(+3)$ & (I) & $1 \S$ & 一 \\
\hline D. & 21. VII & 10 & ${ }^{I}-$ & $I^{*}(+2)$ & 1 & 5 \\
\hline & & & & & 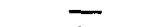 & \\
\hline & & 48 & $14(+3)$ & $7(+4)$ & 8 & I \\
\hline
\end{tabular}

+ In one of these cases two tubers formed (Fig. $18 \mathrm{D}$ ).

* Leaf died off before experiment finished.

\& Developed two ' leaflets' only.

The numbers in brackets refer to leaves fixed for microtoming before fully developed. 
Experimental work was confined to the laboratory for convenience of examination, and because of the uncertainty of the season. The 1917 growing season was a wet one, ${ }^{1}$ especially during the critical months September-October, when most active growth in tuber-production occurs. In $19: 16$ also there had been more than average rainfall, but there was no reason to expect a continuance of the conditions in 1918 , as indeed proved to be the case. In the different experiments. the aim was usually not so much to reproduce the conditions of humidity that obtain in the field, as to maintain. a constant moisture. It is not suggested that an atmosphere so near saturation would be maintained in the field for long together, though

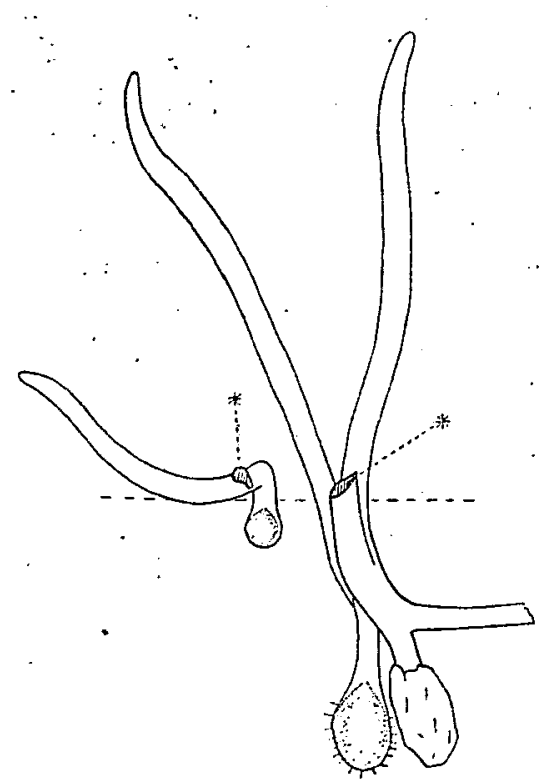

litg. 15 . Three-leaved plant grown in laboratory. One leaf, injured July 17, 1918, has.developed an adventitious tuber. * Marks the wounded surfaces which are contiguous in specimen (Nov. Jo, 1918 ). $\times 3 \frac{1}{2}$. in some years, e.g. 1916, a high rainfall occurred during the last three months of the year, and conditions might remain favourable to tuber production over considerable periods.

In each experiment freshly detached leaves were laid on soil from the locality, kept moist and covered by glass. In the first experiment the soil was lightly tamped down in a Petri dish, but in the subsequent series a sod several centimetres square in which Phylloglossum plants were growing was used. This method was more successful, as will be seen from Series B and $C$, in which 8 and ro leaves gave respectively 7 and 8 positive results, but the first method gave a valuable series of abnormalities, discussed later.

In addition to the five series of experiments, odd leaves were injured but not detached from plants kept in the laboratory, the object being to repeat the conditions under which such plants as those shown in Text-figs. I 3 and 14 grew. Text-fig. I 5 shows the result of such an experiment. One of the three leaves of a plant growing undisturbed in a sod of soil was severely injured but not detached. The plant was dug up and sketched after nearly four months' growth. It had formed a new tuber in the normal way, and the injured leaf, too, had produced a tuber sunken on a short dropper below the surface of the soil. Text-fig. I5 should be compared with Text-fig. 14, which shows a plant collected in the field. The results are closely similar, except that in the experiment the leaf-borne tuber had

\footnotetext{
1 See p. 508 below.
} 
almost reached maturity, while in Text-fig. 14 the cell-mass stage only had been attained by the injured leaf.

An attempt to effect regeneration from portions of cone peduncies gave a negative result. The fragments, about $\mathrm{I} \mathrm{cm}$. long, were laid (July $2 \mathrm{I}$ ) on the same sod of soil as the leaves of Series C. They remained green and turgid for over two months, but early in October began to look unhealthy. On October $2 \mathrm{I}$ one only was noticed to have formed a minute swelling near the middle on the upper side, but this peduncle fragment, like the others, had completely collapsed by the end of the month. It is remarkable, as will be seen below, for what length of time a broken fragment of Plylloglossum will remain green and apparently. healthy on damp soil. On the other hand, once decay sets in it is very rapid, and in a day or two, since there is no hard tissue in the plant, little but the cuticle is left.

\section{(i) Series $B$.}

It will be convenient to consider this series first in some degree of detail, since it gave a high percentage of positive results.

On July II, I9I8, a sod of soil containing many Phylloglossum plants was brought into the laboratory and placed in a glass dish. Eight leaves were broken off various well-developed plants growing in it and laid on the soil. The dish was covered and placed in the strong diffuse light of a south window.

During the first month no growth was apparent; the leaves remained turgid and green, the only visible change being a curving of some of the leaves in the vertical plane. This curving, however, was much less apparent than in some of the other series, especially A.

I was unavoidably absent from the laboratory for the fortnight August ${ }_{5}$ to 31 . Before leaving, the leaves of this and the other series were examined under a hand-lens and the note made that none showed any. "growth. It was feared that all the experiments were failures (Series A had then been running for two months without apparent result). However, every leaf appeared healthy, turgid, and almost as bright green as when first laid upon the soil.

Returning to Adelaide, it was surprising to find, on August 31 , that every leaf of the series showed a distinct protuberance at or near the proximal end (Text-figs. 16-22). Three of the leaves were still lying horizontally; two had the proximal end slightly elevated; the three others were curved crescent-wise with both ends elevated.

The development after this date was comparatively rapid. On September 16 four of the leaves were removed, sketched under the dissecting microscope, and carefully replaced in their original positions (Text-figs. $16 \mathrm{~A}, 17 \mathrm{~A}, 18 \mathrm{~A}$, and $19 \mathrm{~A})$. They all showed irregular, greenish-yellow cell 
496 Osborn.-Some Observations on the Tuber of Phylloglossum.

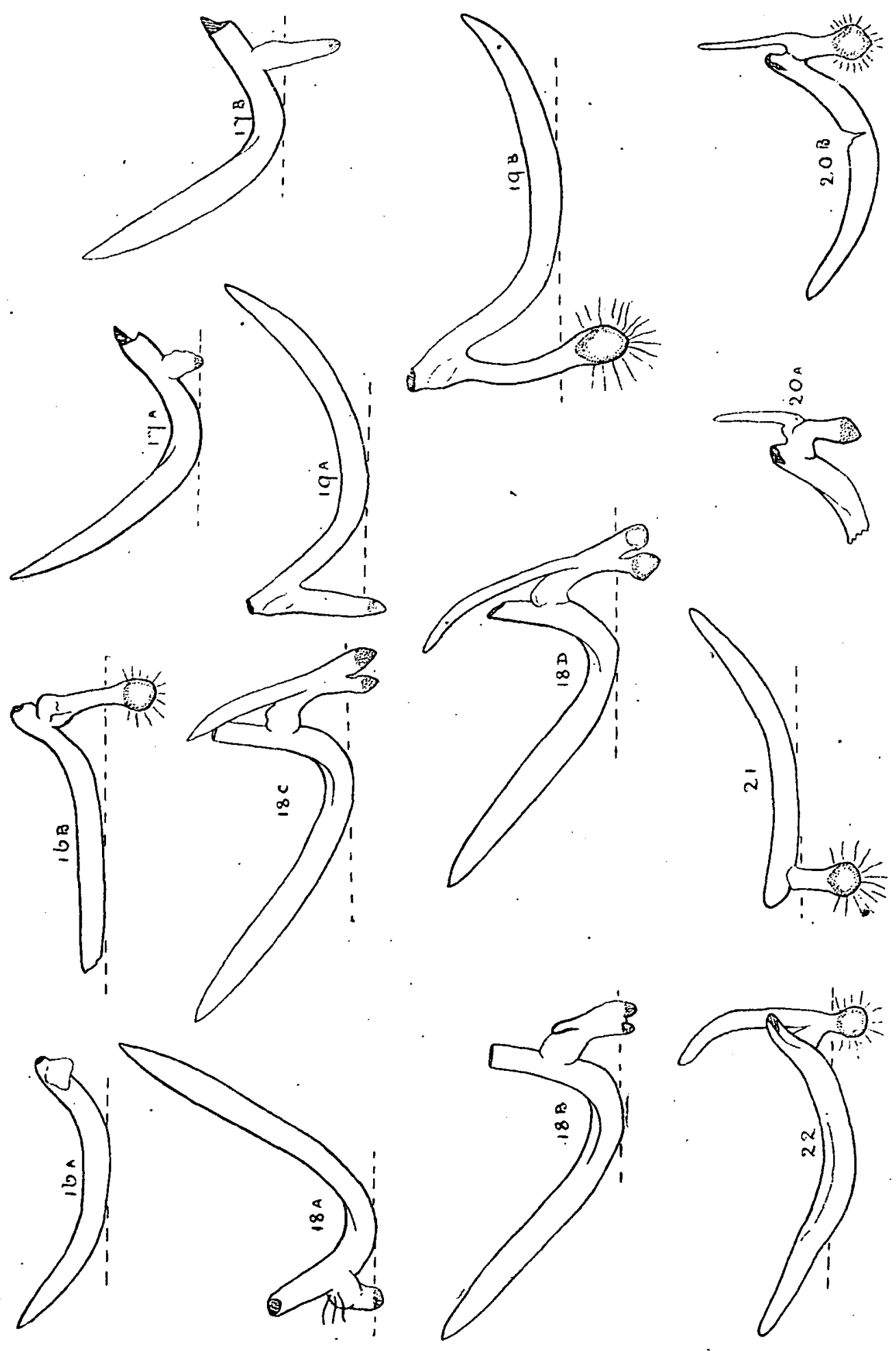


masses. In one case (Text-fig. I6 A) this was all the development visible, but two of the others (Text-figs, $17 \mathrm{~A}$ and $\mathrm{I} 8 \mathrm{~A}$ ) showed in addition a minute white conical projection, arising from the cell mass and growing vertically into the soil. In one case (Text-fig. $18 \mathrm{~A}$ ) rhizoids were visible arising from the cell mass close to the leaf. The fourth leaf (Text-fig. I9 A) showed a comparatively small cell mass, but from it there descended a cylindrical process, 2 to $3 \mathrm{~mm}$. long, that terminated below the soil in a blunt apex. The structure resembled the stalk from which the new tuber of a Phylloglossum plant arises.

By September 24 the leaf shown in Text-fig. $17 \mathrm{~A}$ had made further growth, the growing-point observed upon it having given rise to a descending shaft. It was sketched (Text-fig. $17 \mathrm{~B}$ ) and fixed for microtoming. At the same time it was noticed that the leaf shown in Text-fig. $18 \mathrm{~A}$ showed two new features. First, the growing-point, already observed upon it, was distinctly bilobed ; second, from the upper surface of the cell mass, a minute green leaf-like process was emerging (Text-fig. $18 \mathrm{~B}$ ). The further history of this leaf is shown in Text-figs. $18 \mathrm{C}$ and D, drawn October 8 and November 16 respectively. The green process developed into a slender 'leaflet' $4-5 \mathrm{~mm}$. long, whilst each growing apex developed a white tuberous body at the end of a short stalk.

On October 8 two other leaves were found to have developed leafy processes, one of which is shown in Text-fig. $20 \mathrm{~A}$. The figure also serves to indicate the extent of tuber formation by this date. There is a distinct stalk which carries the growing-point into the soil. The growing-point is swollen and whitish, but as yet quite smooth. The cell mass and such portions of the stalk as are exposed to the light are green. The presence of rhizoids upon.the cell mass was found to be inconstant at this stage. Sometimes they could be distinguished, but more often they were absent. This, however, may have been due to injury, though every care was exercised in removing leaves for observation. Later, as will be seen, the tuber develops many rhizoids.

On October ig one leaf of the series, that had previously been observed to be changing to a dull watery green, was quite collapsed. It

\section{DESCRIPTION OF FIGS. ON OPPOSITE PAGE.}

TexT-FIGS. 16-22. Leaves of Series B, detached and put on soil July 11,1918 . The dates below in brackets are those on which the figures were drawn. All $\times 5 \%$. Fig. 16 A. Cell mass forming (Sept. 16). Fig. 16 B. Same with adventitious tuber (Nov, 16). Fig. 17 A. Growing-point just visible on cell mass (Sept, 16). Fig. I7 B. Same, showing elongation of stalk (Sept. 24). Fig. 18 A. Cell mass with rhizoids and short stalk bearing growing-point (Sept. 16). Fig. 18 B. Same developing two growing-points from cell mass, also ' leaflet ' (Sept. 26). Fig. $18 \mathrm{c}$. 'Leaflet' enlarged, two tubers forming (Oct. 8). Fig. $18 \mathrm{D}$. Same; tubers are smaller and less regular than those formed singly by other leaves of the same series. Rhizoids absent (Nov. 16). Fig. 19 A. Small cell mass, stalk, and growing-point (Sept. 16). Fig. 19 B. Same (Nov. 16). Fig. 20 A. Portion of leaf showing cell mass. Leaflet stalk and tubers beginning to swell. No rhizoids at this date (Oct. 8). Fig. $20 \mathrm{~B}$. Same original leaf beginning to rot (Nov.16). Fig. 21 and 22 . Two remaining leaves of series (Nov. 16). 
was too rotten to remove for sketching, but, on examination, a white rounded body, barely $2 . \mathrm{mm}$, in diameter, was found on the under side near the proximal end of the leaf.! This was the only failure' in the series, and it was not a completely negative result,

$\because \therefore$, By November $1 \sigma_{+}$it was. found necessary to stop the experiment, and the remaining six leaves were all sketched before fixing.- Ait this date the original-leaves were yellowed, and though they still retained-their shape they were found to be mere hollow shells, the mesophyll :being quite collapsed. The leaflets also were yellowing, but the cell mass appeared turgid and green. Text-fig. $18 \mathrm{D}$ shows that the two tubers developed from the single leaf were without any rhizoids. These tubers were opaque and white, but smaller and less regular than those formed singly by the other leaves. The remaining five leaves (Text-figs. I6.D; I 9 B; 20 B, 21, and 22) all showed tubers, borne at the end of more or less: elongate :stalks, externally resembling the tubers normally produced; by Phjlloglossum plants, and having the usual:abundant development of rhizoids that characterizes the later stages of tuber growth. In most cases (Text-figs. $16 \mathrm{~B}, 20 \mathrm{~B}, 21$, and 22) the tuber was sunken for less than $4 \mathrm{~mm}$. below the surface of the soil. $\therefore$ In Text-fig. I $9 \mathrm{~B}$ the stalk is seen to be: much longer. As will have been noticed from Text-fig. I9 A; this leaf showed quite early in the experiment a pronounced upturning of the ends, so that it rested upon the soil by a small portion of its surface only: The resistance offered by the soil to the downwardigrowth of the stalk caused the proximal end to be still further elevated, thus the stalk became unusually elongated.

(ii) Series $C$.

On July 21 ten leaves were broken off plants of Phylloglossum growing in a sod of soil as before, and laid horizontally upon it. In this experiment the sod was placed in a large china developing dish and covered with a piece of plate-glass, in order to secure better illumination. Under these conditions the atmosphere was at a less constant humidity than in Series B, for the glass plate did not fit tightly. While care was taken to prevent the soil drying up, no precautions were taken to keep it constantly damp, for it was felt that by allowing drier periods to alternate with wet ones, field conditions would be more closely reproduced.

$\therefore$. It is unnecessary to describe the results in detail. The leaves, as in Series $\mathbf{B}$, showed no visible change other than curving until after. August: 5 . By August 3 I several were noticed to be forming cell masses near the proximal end, and one was removed for microtoming. It then showed an irregular nodular swelling, yellowish in colour (Text-fig.:23). Three other leaves were removed early in October. Two of these showed irregular cell masses, from the bases of which white growing apices were projecting. 
These subsequently proved to be the growing-point in process of invagination. ${ }^{1}$. The third leaf showed signs of damping off, but it had a short stalk bearing a slightly swollen tuber, enclosed in which the growing-point could be discerned. No rhizoids were present at this stage: All the others appeared healthy, but showed, with one exception, little development above ground. The exception had two 'leaflets' about $4 \mathrm{~mm}$. long, one arising on each side of the leaf and springing from the lower side. Unfortunately, when examined three or four days later, this leaf had collapsed too much to draw. Each leaflet appeared to be attached directly to the main lcal, with no noticeable swelling on or beneath the surface of the soil.
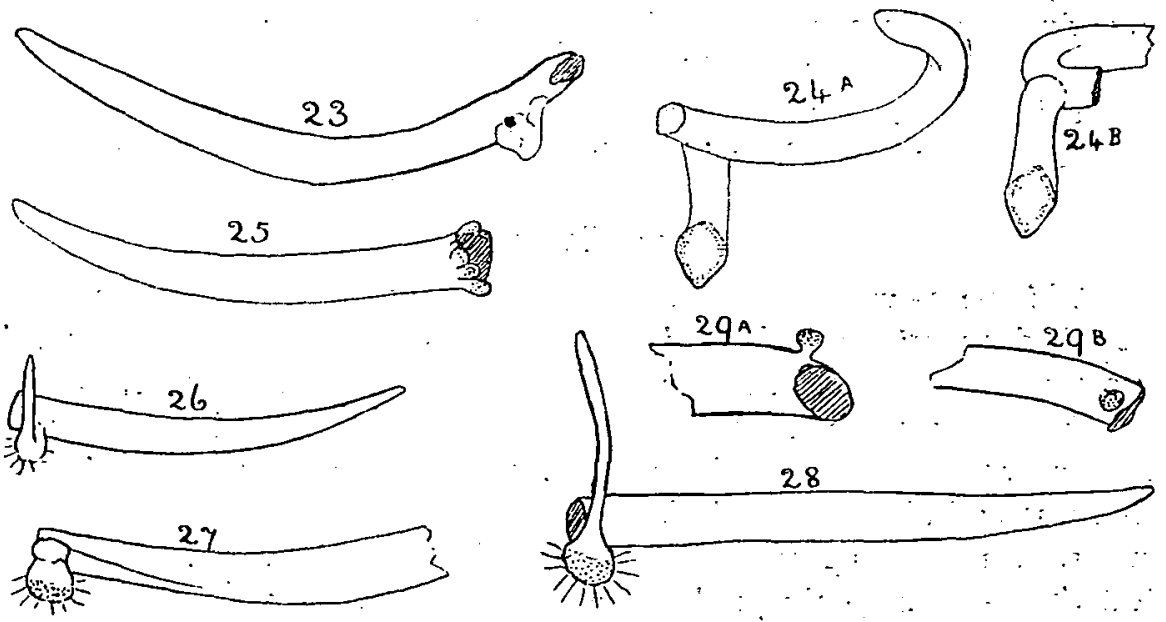

TEXT-FIGS. 23-29. Leaves of various series. The dates below in brackets are those on which the various figures were drawn. All $\times \frac{1}{4}$. Fig. 23. Leaf of Ser. C. The cell mass is nodulose; a T.S. of this leaf is seen Fig. 38 (Sept. 24). Fig. $24 \mathrm{~A}$ and B. Leaf of Ser. C. This leaf curved on soil in horizontal plane. Adventitious growth from convex side (Nov. 16). Fig. 25. Leaf of Ser. D. Note absence of definite growing-point, and formation of many starchy cell masses (Oct. 21). Figs. 26-29. Leaves of Ser. E; for further explanation see text (Nov. 25).

By November 16, almost four months after the experiment was started, the remaining leaves were seen to be yellowing rapidly. They seemed to be mere hollow shells for the greater part of their length, and collapsed when lifted. The base of the leaf, however, was still green, as was the small cell mass: The leaves were all curved, four with their apices erect; the fifth lay curved $\mathbf{C}$-shaped on the soil. In this case also the adventitious growth was from the convex side and so placed that the cell mass originally would not have been in direct contact with the soil (Text-fig. $24 \mathrm{~A}$ and B). Each of the leaves had developed a short stalk bearing a tuber; on which rhizoids were just appearing.

' See p. 504 below. 
joo Osborn.-Some Observations on the Tuber of Phylloglossum.

(iii) Series $D$.

This series was grown on a similar sod of soil to Series $C$ and in the same dish. It was, however, much less successful. The leaves were often buried by the castings of small animals or overgrown by Bryophytes. Two leaves fixed early in October presented a similar appearance to that shown in Text-fig. 23. By the end of the month six of the remainder had damped off. Only one of these showed any adventitious growth, a whitish swelling about $\mathrm{I} \mathrm{mm}$. in diameter near the proximal end on the lower side. The last two leaves were fixed at the end of November, when one showed a dropper, the apex of which was hardly swollen. The other had a series of nodular swellings extending almost around the leaf near the cut surface; several of these appeared white, like minute tubers (Text-fig. 25 ).

It is difficult to account for the comparative failure of this series, unless it were due to competition with various organisms.

\section{(iv) Series $E$.}

This series was not started until September ${ }_{3} 3$, when twelve leaves were laid on soil in a glass dish as above. Three of these collapsed in about a fortnight, and five others before the end of November. Of the remaining four, three (Text-figs. 26-28) each formed a small irregular cell mass near the distal end. Two of these (Text-figs. 26 and 28) produced' ' leaflets'., and all showed rhizoids, but no dropper was developed. The cell masses themselves appeared opaque white, like resting tubers. The fourth leaf (Text-fig. 29) only produced a minute white structure about $1 \mathrm{~mm}$. diameter. This swelling was developed from the surface of the leaf remote from the soil.

\section{(v) Series $A$.}

The consideration of this series has been postponed until the other experiments had been described, because, of the eight leaves used, only one formed a single tuber (Text-fig. 30 ) in the manner described above. All the remainder produced abnormalities.

As has been explained, the conditions of the experiment were slightly different, in that soil from the locality in which Phylloglossum was growing was placed in a Petri dish and lightly tamped down, instead of using an undisturbed sod. Water was sprayed over the soil from time to time to keep it moist. Though the experiment was begun on June 13, nearly a month before any other series, no development occurred until the latter end of August, by.which date all other series also showed growth. The only noticeable feature displayed by the leaves during the first two months was the remarkable curving exhibited by them. With a single exception, in which case the leaf lay flat along the soil throughout the five months the 
experiment lasted, all the leaves early began to curl upwards, becoming $\mathrm{J}$ or U-shaped as one or both ends were elevated.

The curling was not due to the effect of light, for frequently the proximal end was elevated, whilst the apex showed no response. It was noticed that in dry weather the leaves of plants growing in the field might show a marked incurving of their tips. It therefore appeared probable that the curving was due to some alteration in the turgidity of the leaf. This point is further discussed later (p. $5 \mathrm{IO}$ ).

By August 31 all the leaves showed more or less adventitious growth near the proximal end. Most of the cell masses were lifted above the soil owing to the curvature of the leaf. All of them had an irregular contour. The appearance about this date is shown in Text-figs. $3^{1}$ and $3^{2} \mathrm{~A}$, drawn September 16 . As it was feared that the cell masses might dry up because of the elevation of the proximal ends, some of the leaves were laid flat upon the soil. On October 21 the leaf shown in Text-fig. $3^{2} \mathrm{~A}$ was sketched again (Text-fig. $32 \mathrm{~B}$ ). It will be seen that the cell mass now showed distinct scattered nodules. These were green, no white growing-point being seen.

By the middle of November it was necessary to stop the experiment. Only one leaf (Text-fig. 30), that which lay horizontally, showed a single tuber resembling those formed in the other series. Text-fig. $32 \mathrm{C}$ shows the condition of the leaf drawn in Text-figs. $32 \mathrm{~A}$ and $\mathrm{B}$. The nodular growths noticed before had most of them elongated to form minute stalks terminating in slightly swollen white heads. Text-fig. 33 A shows another leaf viewed from above. The cell mass is seen to be near the proximal end, but on the convex side of the curved leaf. Stalklets bearing small white heads are visible. Viewcd from the side (Text-fig. $33 \mathrm{~B}$ ) it is seen that these minute tuber structures, developed irregularly over the cell mass, are markedly geotropic in their growth, though several of the stalks were not sufficiently elongated to bury their apices. The leaf shown in Textfig. 34 A (also drawn from above) had its apex erect. From the under surface of this (Text-fig. $34 \mathrm{~B}$ ) many irregular white nodular structures of various sizes were developed.

The leaf shown in Text-fig. 35 is interesting. In this case the adventitious cell masses were scattered over a greater length of leaf than is usual. The majority of them merely developed short stalks in the white swollen heads. Two of the growths, however, developed leaflets as well as descending portions. By November 17 the original leaf was obviously dying off, so that it was necessary to fix it, and further development could not be followed. It will be noticed, however, that each leafletbearing structure resembles that shown in Text-fig. $20 \mathrm{~A}$, -but at an earlier stage. 


\section{Osborn.-Some Observations on the Tuber of Phylloglossum.}
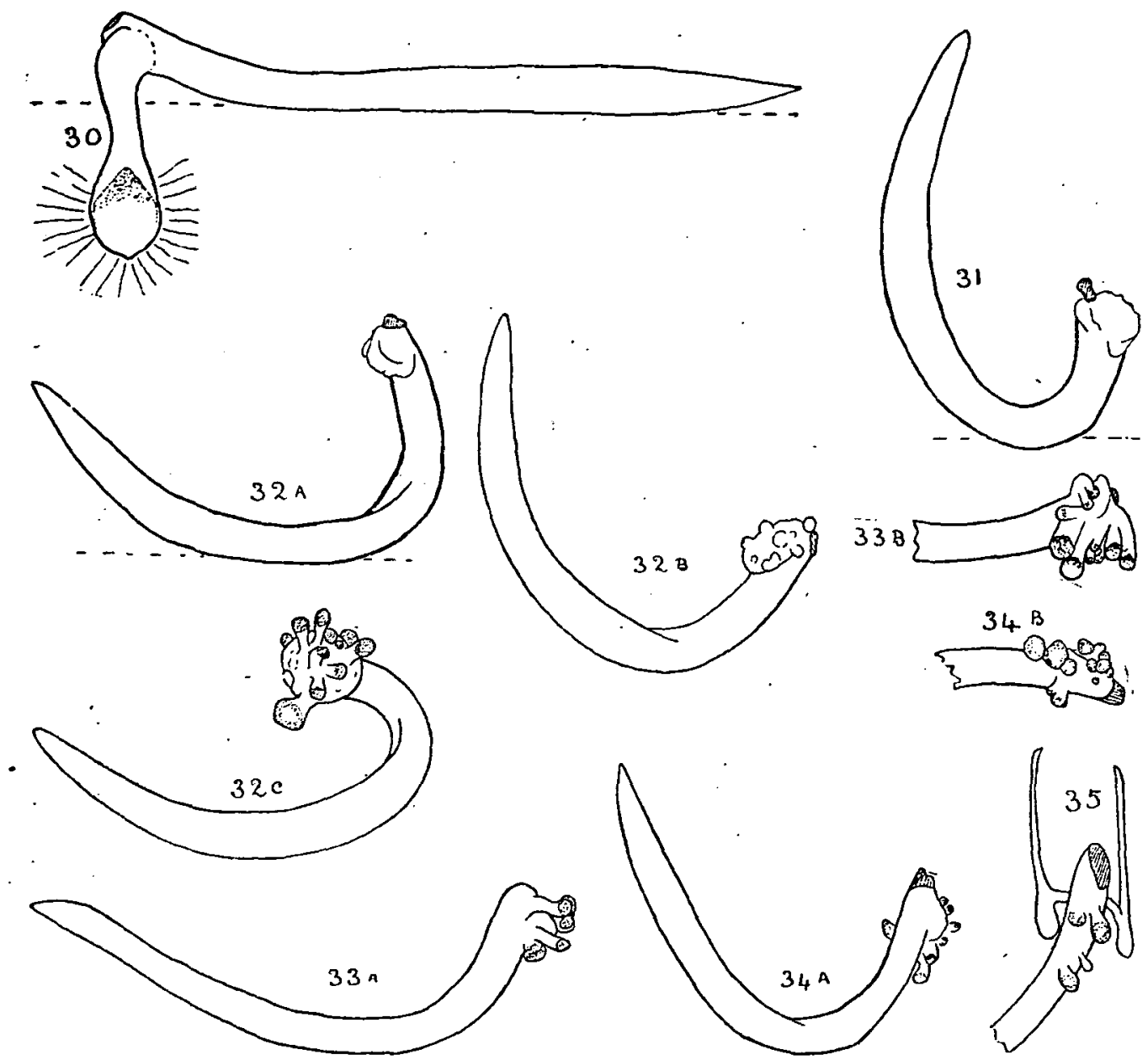

TexT-FIGS. 30-35. Leaves of Series A, detached and put on soil, June 13, 1918. The dates below in brackets are those on which the figures were drawn. All $\times 5 \frac{1}{4}$. Fig. 30. Adventitious tuber arising from side (Nov, 16). Fig. 31. Extreme case of leaf curvature in vertical plane. Cell mass nodular (Sept. 16). Fig. $32 \mathrm{~A}$. Leaf showing vertical curvature. This leaf appears to be an exception to rule that adventitious growth occurs from convex surface (Sept. 16). Fig. 32 B. Same, viewed from above; note nodular development of cell mass. This leaf was laid flat on soil Sept. 16 (Oct. 21). Fig. 32 c. Same; note many short-stalked, white, swollen bodies (Nov. 27). Fig. 33 A. Leaf viewed from above, and $\mathrm{B}$, viewed from side, showing geotropic curvature of the many minute, stalked tubers (Nov. 27). Fig. 34 A. Leaf viewed from above, and B, viewed from below (Nov. 26). Fig. 35. Portion of leaf, viewed from side, with several scattered centres of adventitious growth. Two have developed leaflets and small tubers (Nov. 17).

\section{Developmental History.}

The first slage in adventitious tuber formation is the development of a pad of tissue or cell mass, projecting from the epidermis, at or near the proximal end of the detached leaf. This projection is due to the activity of certain epidermal cells; usually several are involved, but it would appear 
from those abnormal cases in which a number of minute tuberous bodies is formed (e.g. Series A) that each may arise from the activity of a single epidermal cell (Text-fig. $3^{6}$ ).

: The epidermal cells, which are considerably elongated in the direction
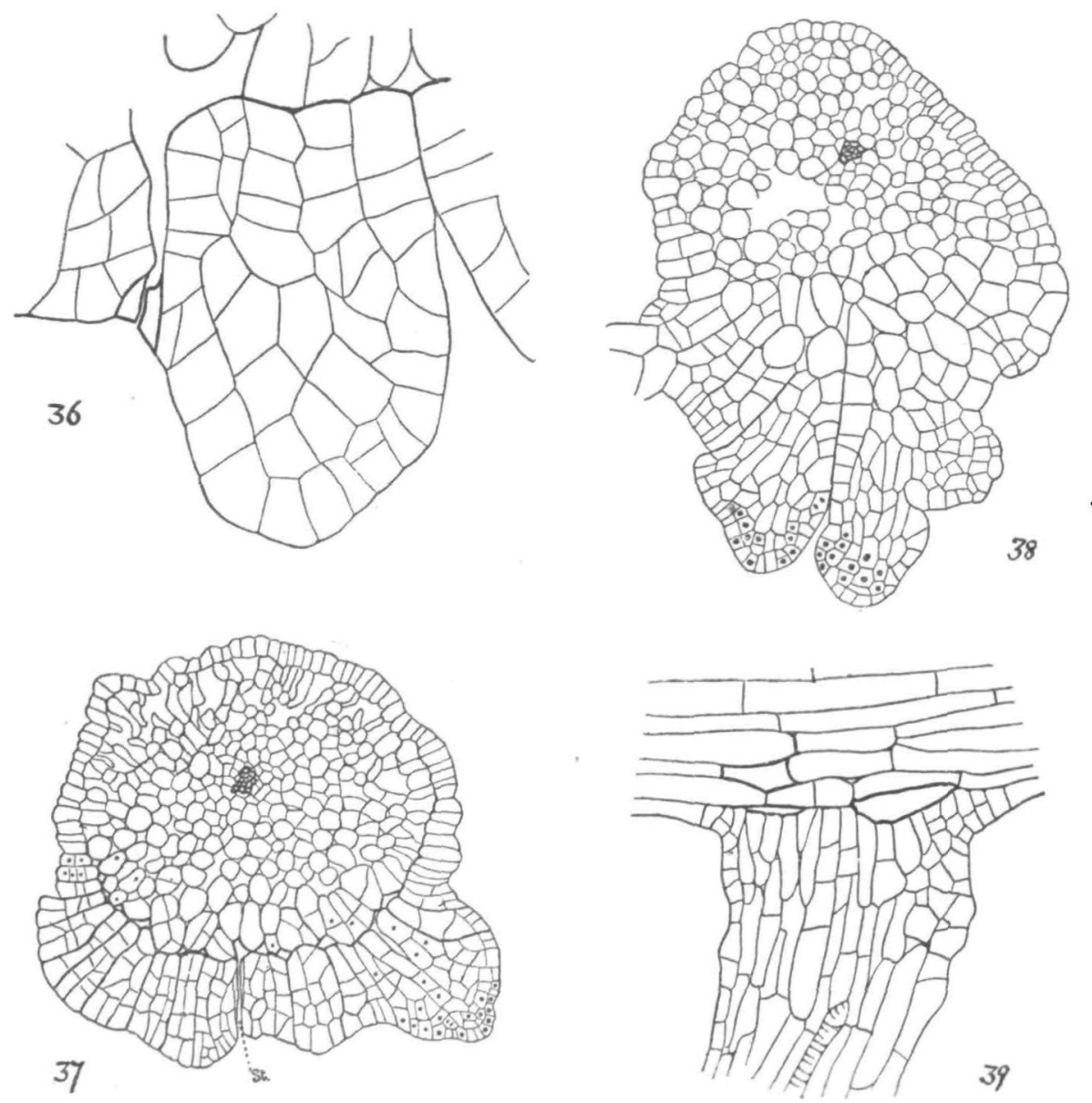

Text-fic. 36 . Portion of transverse section- of leal showing adventitious growth from single epidermal cell. Stomate seen to left. $\times 180$.

TEXT-FIG. 37. Transverse section of leaf showing considerable cell mass of epidermal origin, interrupted by stomate at $S t$. Growth is becoming localized by development of growing-point seen at right. $\times 44$.

TEXT-FIG. 38. Transverse section of leaf (see Fig. 23). Two growing-points are developing; the anticlinal walls separating the groups of epidermal cells involved are plainly seen. $\times 44$. $^{\circ}$.

TEXT-FIG. 39. Portion of longitudinal section showing junction of leaf tissue and cell mass showing epidermal origin of latter. Cell mass developed stalk in which a 'tracheide' is seen. $\times 44$.

of the leaf axis, first divide transversely, and at the same time the segmented cells enlarge in a radial direction. The radial elongation is accompanied by periclinal division. 
The evenness of contour of the cell mass thus produced depends on how nearly equal the stimulus to division has been in neighbouring cells, and upon the absence of stomates from the proliferating area (Text-fig. 37 and PI. XXVIII, Photo I). In Text-fig. $3^{8}$ and Photo 2 it is obvious that growth has been less regular, the boundary between original groups of epidermal cells being clearly shown by anticlinal planes of division, extending for as many as eight or nine cell rows. There is thus developed a considerable cell mass due entirely to proliferation of the epidermis. Concurrently the sub-epidermal cells enlarge somewhat, and a few irregular walls are formed. These are best seen in a section tangential to the leaf-surface, when they resemble the secondary changes that may occur in the cortex of some herbaceous plants (Photo 4). In no case has the sub-epidermal tissue been observed to take any part in the structure of the main adventitious cell mass (cf. Text-fig. 39 and Photo 5), though in cases where the growth is close to the injured surface the activity of the sub-epidermal cells is greater than usual (Photo 4). The changes that occur within it are of such a nature as to reduce the amount of intercellular space below the adventitious mass, thus permitting of freer translocation between it and the leaf.

The size of the cell mass produced appears to be directly related to conditions of growth. In contact with the soil or in very humid atmosphere, it may be small in amount; in drier conditions growth is slower and a considerable and very irregular mass may be produced before further differentiation proceeds. A further factor, that of the age of the regenerating leaf, is discussed below. It has already been noticed that rhizoids were not of constant occurrence upon the cell mass, though they invariably occur in large numbers upon the tuber in the later stage of development.

Once the cell mass is formed the next stage is the localization of growth at one or more centres by the differentiation of growing-points (Text-figs. 37-8 and Photo 3) consisting of a group of meristem cells. The growing-point is definitely geotropic, and quickly becomes buried in the soil. When, owing to its growth, the apical meristem has become buried, an invagination of the growing-point occurs as a result of unequal growth. This is well shown in Text-fig. 40 and Photo 6, which shows the growing apex already invaginated, and lying at the base of a short pit. In the case of this leaf a considerable irregular cell mass was formed owing to there being more than one centre of proliferation. However, only one growing-point developed.

The subsequent growth of the stalk, after invagination of the apex, resembles that described for the normal new tuber. The apex is buried by intercalary.growth of the stalk cells, which become considerably elongated in the vertical plane (Text-fig. 39 and Photos 5, 8, and 9). As in the normal tuber, the apex is in communication with the exterior along a channel ('Canal de Braun' of Bertrand) (Text-fig. 41). This, as usual, 
dilates at the distal end to form a chamber into which the growing-point projects (Text. figs. $4 \mathrm{I}$ and 42 and Photos $7,8,9$, and II).

In the majority of cases it is not until the apex is well buried that growth takes place in all directions, resulting in a tuber. This has the usual conical meristem seated on a spherical mass of parenchyma (Photo 7). All the essential features of a normal tuber of Phylloglossum are shown in this section made from a detached leaf after three months' growth. At this
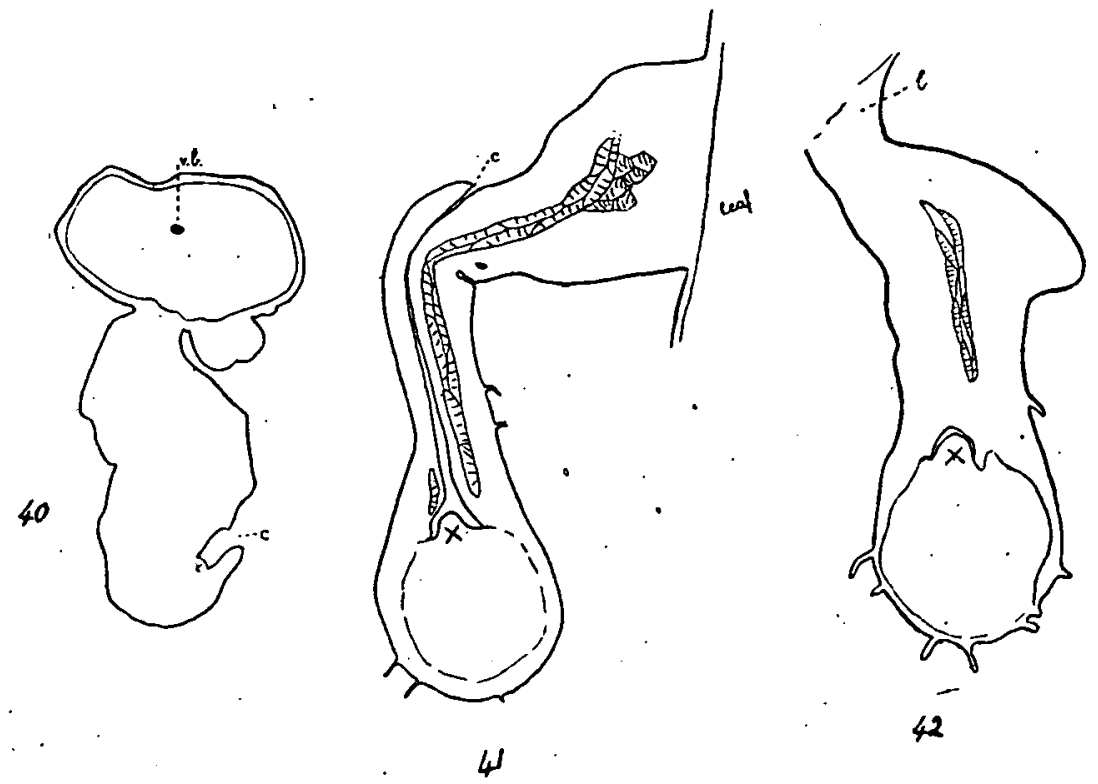

TeXT-FIG. 40. Transverse section of leaf; epidesmis indicated by faint line. An irregular cell mass has formed, and the growing-point has begun to invaginate. $c$. = opening of channel, z.b. = vascular supply of leaf. Camera lucida outline. $\times 26$.

TEXT-FIG. 4I. Portion of longitudinal section through cell mass, stalk (which was accidentally bent), and tuber. 'Vascular supply' seen from its expansion in cell mass to cup of 'tracbeides' around growing apex $(x)$. Apex projecting into the chamber and seated on spherical mass of starchy tissue. The whole length of channel shown. $c=$ opening of channel. Camera lucida outline. $\times 26$.

TEXT-FIG. 42. Longitudinal section of adventitious growth on leaf in Fig. 20 B. A pex $(x)$ seen projecting into chamber; extent of starchy tissue shown by faint line. Greater part of 'vascular supply' seen, extending towards 'leaflet' (l.) (which passes out of plane of section), but no 'leaflet' bundle differentiated. Camera lucida outline. $\times 26$.

stage, however, tuber and dropper consist entirely of parenchyma. Subsequently a 'vascular supply' is developed and differentiation proceeds within the tuber.

The 'vascular supply' consists of a strand of tracheidal cells, with loose spiral or reticulate markings, extending from the original cell mass along the dropper to a point at the level of the apical meristem. This development is most active during the last month of growth, and results in the lignification of certain of the parenchyma cells. These agree with their 
506 Osborn.-Some Observations on the Tuber of Phylloglossum.

neighbours in size and shape, hence in the cell mass the 'tracheides' are more or less isodiametric (Photo 10), while in the dropper they are elongate. Within the adventitious cell mass the 'tracheides' form a broad core

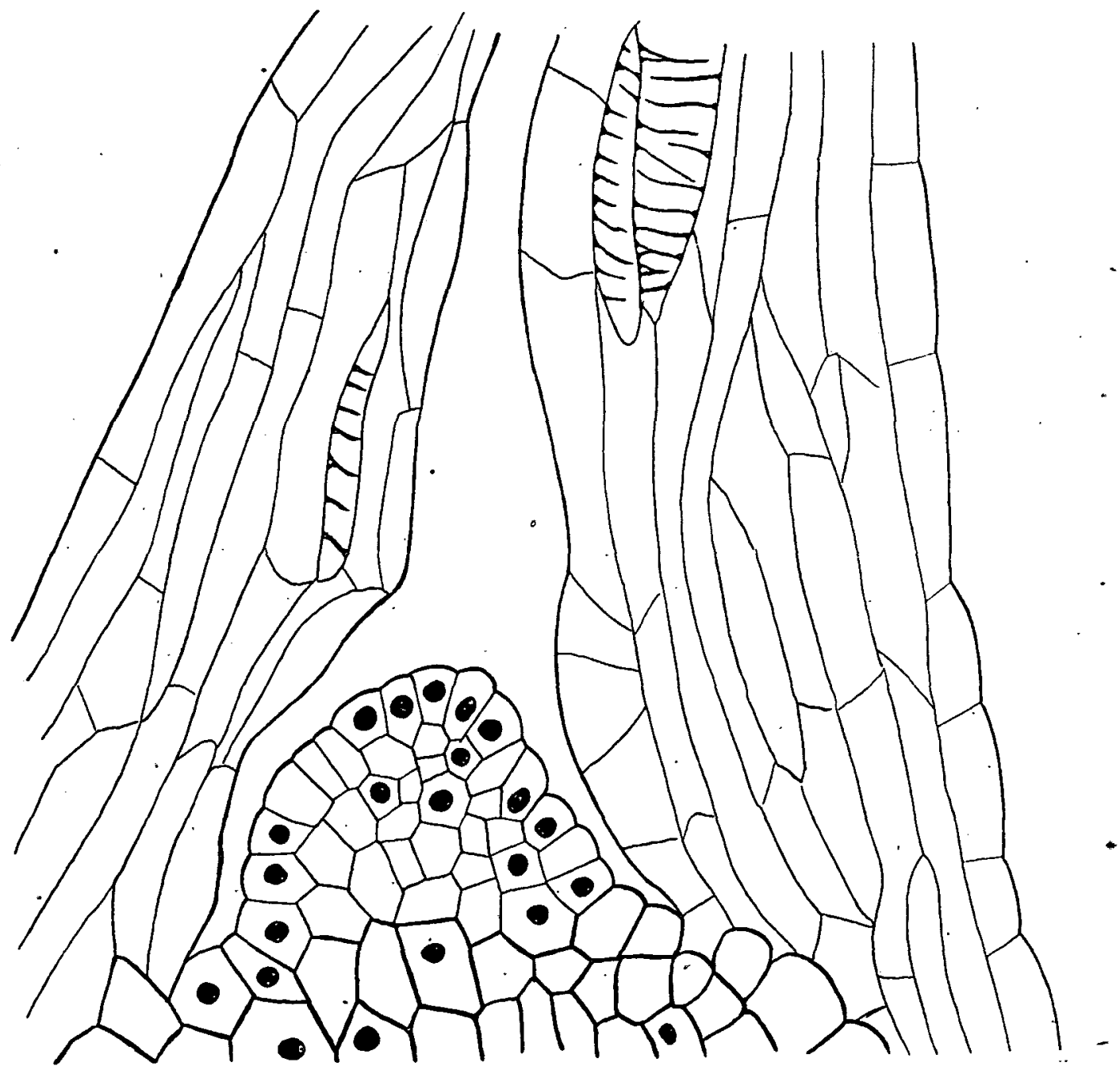

TExT-FIG. 43. Detail of apex of tuber seen Fig. 4t. Starchy tissue indicated by heavier outline to cells. $\times 270$.

extending towards the original leaf but not reaching so far as subepidermal tissue, hence, of course, they never form a connexion with the leaf trace. In the tuber stalk it is interesting to observe the vascular supply may expand to form a cup of 'tracheides' around the apex (Textfig. 43), as has been described in the normal tuber." Whilst lignification is

1 Wernham, H. F. (1910) : loc. cit., p. 388. 
proceeding the tuber becomes further differentiated. The outer layer or coat consists of rather large cells with stout cell walls, and numerous rhizoids are developed (Photos 8, 9, IO, and II). The coat rarely is more than one cell thick, and in irregular tubers may be absent. In this respect it differs from the new tuber coat described by Bower, ${ }^{1}$ which consists of two or three cell layers besides the epidermis, the latter having characteristically thickened walls and rhizoid-like hairs. The tissue comprising the main body of the tuber consists entirely of parenchyma, with few intercellular spaces. This tissue is packed with minute starch grains, and forms an almost spherical body of cells, near the upper pole of which the growing apex is found. The cells of the apex are clearly differentiated from the rest of the tuber by their large nuclei, abundant protoplasm, and the absence of cell inclusions. The appearance of a fully-developed adventitious tuber is well shown in Text-figs. $4 \mathrm{I}, 42$, and Photos 8, 9, I I, especially Text-fig. $4 \mathrm{I}$, which shows the 'tracheide' strand from its expansion in the adventitious cell mass, throughout its whole length, to the cup around the tuber apex. The same section also shows the channel throughout its whole length, including the rather prominent opening to the exterior (see also Photo 10). The position of this shows that invagination of the apex did not occur till after an appreciable amount of geotropic growth had occurred. Only two adventitious tubers showing 'leaflets' developed from the cell mass have been examined in serial section. The 'leaflet' structure is exceedingly delicate, and consists of an epidermis, a spongy mesophyll, with large intercellular spaces and a central strand. In one 'leaflet' this central strand consists of elongate parenchyma only, and, as the main leaf had already begun to rot when fixed, little further development could have occurred. In the other case there was a well-developed vascular strand seen in transverse section to consist of 4-6 larger 'tracheides' around two or three smaller ones. This vascular strand passed down the leaflet and connected with the tracheidal cells in the cell mass. It was noted that certain epidermal cells of the leafiét near to its apex developed fine rhizoid-like processes.

\section{General Results and Conclusions.}

The observations on the behaviour of the tuber of Phylloglossum recorded in the opening sections of this paper serve to emphasize the importance of the structure as an organ of perennation. This view, referred to by Professor Bower in his Presidential Address to Section K of the British Association, $1914,^{2}$ expresses more nearly the true value of the tuber than one which regards it as an annually produced protocorm developed by a permanently embryonic Lycopod.

\footnotetext{
1 Bower, F. O. (1885) : loc. cit., p. 666.

2 Bower, F. O. (1914) : Brit. Ass. Report, p. $5^{6} 5$.
} 
508 Osborn.-Some Observations on the Tuber of Phylloglossum.

In South Australia the geophytic element in the flora of certain areas is very large. ${ }^{1}$ Physiologically the tuber of Phylloglossum is comparable with the tubers, corms, \&c., of the spermophytes among which it grows. Like them, it has an average depth to which the perennating organ is sunken, a depth that it maintains in spite of accidental circumstances that tend to bury or expose the tuber. In this. respect its behaviour agrees with that of the geophytes of other countries. ${ }^{2}$

The analogy drawn by Wernham ${ }^{3}$ between the tuber of Phylloglossum and the stalked droppers of Tulipa and Erythronium described by Mrs. Arber ${ }^{4}$ seems particularly apt, though other workers have found nothing to justify his conclusions as to the morphological nature of the tuber.

It may naturally be asked how far the development of adventitious tubers upon leaves is a normal occurrence and so of value for purposes of vegetative reproduction. Unfortunately no definite answer could be given to such a question. In rig 7 seven leaves in various stages of tuber formation were collected in the field. Had these been left undisturbed, possibly not more than two of them, those shown in Text-figs. 8 and 12, would have developed sufficiently to be of value for vegetative propagation before the oncoming dry season put a stop to all growth. On the other hand, in certain seasons the district near to Adelaide in which Phylloglossum grows may remain green and growth be possible until the end of December. In

\section{RaINFall in INChes at Belair, South Australia. Altitude $\cdot$ I, OO9 FT.}

\begin{tabular}{|c|c|c|c|c|c|c|c|c|c|c|c|c|c|}
\hline Year. & Jan. & $F_{e} b$. & Mar. & $A p l$. & May. & June. & July. & Aug. & Sept. & Oct. & Nov. & Dec. & Total. \\
\hline 19 & 0.6 & $0 . c$ & & 2.5 & $4 \cdot 20$ & 6.92 & $\mathbf{3} \cdot 88$ & 4. & 5.09 & 4 & $0.3^{6}$ & 7 & .82 \\
\hline 19 & 0.6 & 0.1 & & 2.18 & 1.20 & 11.08 & & 5 & 1.96 & & 4.08 & 1.26 & 34.58 \\
\hline 1917 & 0.50 & 2.77 & $3 \cdot 2$ & $1 \cdot 39$ & 6.92 & 4.53 & $5.9 \mathrm{i}$ & $4.4 \mathrm{I}$ & $5 \cdot 54$ & 3. io & 1.23 & 1.29 & 40.86 \\
\hline 1918 & $\left|0.6_{3}\right|$ & 0.63 & 0.4 & $1 \cdot 5^{8}$ & $3 \cdot 86$ & 4.88 & $3 \cdot 3^{2}$ & $4 \cdot 14$ & 1.35 & 4.39 & 0.45 & 0.60 & $26 \cdot 34$ \\
\hline Rainfall & 0.99 & 0.65 & & 2.50 & & & & & 2.81 & 2.24 & $\mathrm{I} \cdot 43$ & I. I 2 & $28 \cdot 63$ \\
\hline $\begin{array}{l}\text { for } 3^{8} \\
\text { years }\end{array}$ & 0.99 & & 1.39 & 2.59 & 3.39 & 495 & 3.50 & $3.3^{2}$ & & 2.24 & 1.43 & & \\
\hline
\end{tabular}

such circumstances there is a reasonable chance that most leaves which began to form tubers would mature them. In this connexion it is interesting to recall that in some spots a considerable percentage of single-leaved plants was observed at the close of the 1917 growing season. ${ }^{5}$ Many of these plants were very minute, yet all were from tubers of a preceding season. The year before, 1916 , was unusually wet during November. ${ }^{6}$ It

1 Osbom, T. G. B. : loc. cit., p. 9.

${ }^{2}$ Goebel, K. (1905): p. 466.

3 Wernham, H. F.:- loc. cit., p. 343.

[ Robertson, A. (1906): Ann. Bot., xx, p. 429.

Osborn, T. G. B.: loc. cit., p. 4. Of 184 plants 39 bad one leaf only.

- I am indebted to Mr. E. Bromley, State Meteorologist, Commonwealth Meteorological Bureau, who has kindly furnished the rainfall records at Belair which are given above. 
is possible that some of these single-leaved plants were formed from leaves detached during the 1916 growing season, especially as in many instances the tubers from which they arose were very small and placed near to the surface of the soil. When plants of Phylloglossum are turgid their leaves are brittle and easily broken through. Apart from animal agency, a blow from a falling twig or even a wind-swept leaf. of Eucalyptus might detach one.

The production of adventitious tubers by leaves of Phylloglossum has an interest quite apart from considerations of the morphology of the plant producing them, namely, as an instance of regeneration. It will have been observed that the adventitious cell mass produced on injured leaves invariably arises at or near to the proximal end of the leaf. In this respect it differs from the position of the cell mass formed in regeneration from detached leaves of Lycopodium ramulosum described by Holloway. ${ }^{1}$

There the leaf shows no polarity and the adventitious structure may be produced from any point. However, this may result from the small size and apparently unspecialized nature of the leaf in question. In Phylloglossum, the consistent development of the adventitious growth at the leaf base agrees with Goebel's generalization - 'that the place for the formation of new organs in regeneration is definite and is primarily dependent upon the direction in which the plastic substance moves in the uninjured plant.' ${ }^{2}$

But a further consideration arises which is obvious from a study of the figures, namely, that while the cell mass invariably arises near the leaf base, it is apparently immaterial upon which side it develops in relation to the soil. In most cases it is developed from the side of the leaf next the soil, even when this is elevated by curvatures of the leaf well above the wet ground. But Text-figs. I2, 24, 33, show that it may be lateral to the leaf as it lies on the soil, and in one case, Text-fig. 29 , it is from the upper side, i. e. that remote from the soil. Moreover, it has been noted that, with a single possible exception, the adventitious growth in those leaves which exhibit curvature is always from the convex side. Hence it seems that it is not merely the stimulus of contact with the damp ground which determines the position of adventitious growth, but a morphological factor must be taken into consideration as well. Unfortunately it was not thought necessary to mark the morphological upper surfaces when detaching the leaves, and, as these appear nearly cylindrical, it is difficult to recognize afterwards, but it is possible to arrive at some conclusion from a consideration of structurc. The anatomy also serves to explain the curving of the leaves to which reference has already been made.

The main features in the structure of the leaf are already well known.

1 Holloway, J. E. (1916): Trạs. N.Z. Inst., xlix, p. 88, Figs. 14-20.

2 Goebel, K. (1900) : p. 45 . 
In section it is said to have an almost circular outline. ${ }^{1}$ This is true of the leaf for the greater part of its length, but towards the base it is usually decidedly elliptical and sometimes becomes, by compression against the other leaves, segment-shaped. The usual result of this is that the leaf, when detached, lies either on the abaxial or adaxial surface, generally the latter, aud seldom on its side. Further, the simple leaf bundle, which is said to lie in 'the centre of the transverse section', only has this position in the upper portion of the leaf. Towards the base it lies on the minor axis of the ellipse but displaced from the median line, being nearer to the adaxial surface (Text-fig. 40 and Photos 2 and 6). More than 'four or five xylem elements' have been found in transverse section; the number is usually ten or more near the base. This eccentric position of the leaf bundle within the somewhat flattened leaf has the effect of producing curvature when turgidity is reduced, and it is the abaxial surface which becomes convex under such circumstances. The inference, therefore, is that the adventitious growth occurs from the abaxial surface. This conclusion is supported by the transverse sections seen in Text-figs. $37,3^{8}$, and 40 and Photos 2 and 6. It is less easy to judge from longitudinal sections, in which plane most of the leaves were cut, but Photo 7 supports this conclusion.

The amount of adventitious growth made by the leaves of the various series was markedly different. The difference can be correlated with the period of the growing season at which the leaves were detached. The series may be conveniently placed in three groups: A, started early in the growing season (June 13 ), a little after the tips of the largest leaves were noticed above the soil ; B, C, and D, started in July, when the plants had been growing for at least six weeks in the field; and $E$, started two months later (September I3). Series B and C were very successful. ${ }^{2}$ Of the 18 leaves involved, I 2 matured tubers and 3 others would probably have done so had they not been removed for sectioning before the tubers were fully developed. The remainder all showed some growth. Series E, on the other hand, was a comparative failure. Unlike the leaves of the other series, which remained green for four months or longer, many of the leaves of this series quickly rotted away. Four only formed any growth, and in the case of one of these it was very slight. The remaining three leaves only developed as far as the cell mass; this, however, became white and starchy and in two instances formed a 'leaflet'. During the two months, July 21 to September 13, which elapsed between starting Series C and E, considerable development occurred in the new tubers formed by plants growing in the field. In July the new tuber merely showed a stalk in process of elongation with a small unswollen apex. By September the stalk had reached its full

1 Bower, F. O. (1885): loc. cit., p. 673. The other quotations in this paragraph are from the same source.

${ }^{2}$ It seems legitimate to neglect Series $D$, since its failure may be attributed to other reasons than the age of the leaves. 
length and the new tuber was appreciably swollen, showing that considerable plastic material had been transferred to it. By the latter date the leaves of the growing plant were presumably depleted, although they did not appear senile, and the phase at which regeneration could be successfully accomplished was nearly over.

In regeneration a cell mass is invariably formed first. Upon this a growing apex usually differentiates, from which the starch-containing tuber develops. But in some cases no apex is formed and the cello mass itself becomes starchy as the growing season concludes (Series A and E). Thus the cell mass may, under some circumstances, behave as a perennating organ. The essential feature of the cell mass is that it is a roughly spherical structure, in which carbohydrate material may accumulate, but which is capable of producing further growth after differentiating a growingpoint. The occurrence of a 'leaflet' upon the cell mass is variable. In Series $E$ two of three leaves developed one, but in Series B the three leaves that did so produced the 'leaflet' only after a considerable amount of adventitious growth had taken place. This suggests that the 'leaflet' is a structure of secondary importance, produced in response to some such physiological stimulus as a failing or insufficient carbohydrate supply. The cell mass is, as it were, the first foothold secured by a young plant, a starting-point from which further developments may occur, circumstances being favourable. Small parenchymatous swellings containing starch are not uncommon amongst minute plants in regions of rapidly varying humidity. A species of Fossombronia growing beside Phylloglossum has a thallus with a markedly swollen midrib. The tubers of certain Australian species of Anthoceros are well known. Near to the locality in which Phylloglossum occurs, Anogramme leptophylla grows in abundance. This has a peculiar prothallus with a small, starchy tuber. ${ }^{1}$ Bearing in mind the climatic conditions under which it grows, the early and constant production of a cell mass gives special interest to the behaviour of regenerating leaves of Phylloglossum, and to any comparison that may be made between them and those of certain species of Lycopodiuml

Cases of vegetative reproduction in the genus Lycopodium are well known, the example of adventitious shoots produced by the first leaves of embryo plants of Lycopodium inundatum cited by Goebel ${ }^{2}$ being of special interest in considering the behaviour of Phylloglossum. Our knowledge of vegetative reproduction and regeneration within the former genus has been considerably extended of late by Holloway. ${ }^{3}$ Specially valuable for comparison with the structures described in Phylloglossum are the gemmae produced from old roots and from detached leaves of L. ramulosum. The gemmae." formed from detached fragments of roots are stated to arise from

\footnotetext{
1 Goebel, K. (1905) : p. 216.

3 Holloway, J. E. (1916); loc. cit.

2 Goebel, K. (1900) : p. ${ }_{4} 6$.

4 Loc. cit., p. 8 .
} 
cortical cells. The youngest stages show the development of transverse walls in certain cells from which a cell mass subsequently forms, which swells externally and produces a "protophyll : The following account ${ }^{1}$ of development of leaf bulbils is given. 'An adventitious bud on a leaf shows first as a small, roundish, green cushion of meristematic tissue which has originated probably. from one or more epidermal cells. This cushion develops into a roundish or egg-shaped cell mass which gradually elongates, and on which at an early stage rhizoids arise. The attachment of the young bud ... shows that the main tissue of the leaf is undisturbed.' These buds produce one to three 'protophylls' and are firmly attached to the substratum by rhizoids. Both 'protophyll' and swelling are packed with starch grains, especially the latter, which develops a storage tissue. The parent leaf is 'greenish at its upper portion but yellowish below and is always obviously broken off at its lower extremity'. The bulbil is subsesequently freed by rotting away of the leaf. These bulbils Holloway compares with the protocorm of $L$. cernumn.

If the term 'protocorm' is to have any morphological value it is well that it should be limited to certain structures such as the extra-prothallial swelling of the embryo of $L$. cernumin and to the similar structures formed in $L$. laterale ${ }^{2}$ and L. ramulosum. ${ }^{3}$ In the last two species the protocorm is of unusual size, but Holloway points out that in this large structure two portions may be recognized, 'the original protocormous tuber surmounted by its two protophylls' and 'the thizomatous extension-an added feature to be interpreted apart from the original tuber'. From an examination of material of $L$ : laterale, collected by him in Tasmania, the writer is inclined to agree' with this distinction. It is thus 'the protocormous tuber' of $L$. laterale which is the homologue of the protocorm of $L$. cermunm. However, seeing ' that vegetatively produced plants (from bulbils, gemmae, $\& c$.) tend in their development to pass through stages in elaboration similar to young plants developing from spore or zygote', Holloway's extension of the term protocorm to the starch-containing bulbils of $L$. ramulosum and L. laterale seems perfectly justifiable. But it is unlikely that the protocorm, even so defined, has any phylogenetic significance. ${ }^{5}$ It seems preferable to regard it as 'an'opportunist local swelling . . , which, though biologically important . . . is not really primitive.' 6

The biological importance of the protocorm becomes increasingly obvious as our knowledge of the ecology of those species of Lycopodium which produce it is enlarged. From Holloway we learn that the three New

1 Holloway, J. E. (1916): loc. cit., p. 88.

2 Holloway, J. E. (1914): 'Trans. N.Z. Inst., xlvii, p. 73 , and ibid. (1915), p. 277.

3 Holloway, J. E. (1915) : loc. cit., p. 28 5.

4 Lang, W. H. : Brit. Ass. Report, 1915, p. 706.

Bower, F. O. (1908): p. 225.

6 Bower, F. O. (1914): p. 565 . 
Zealand species of $L y c o p o d i z m$ which form protocorms all have short-lived prothalli ${ }^{1}$ and grow in localities that are subject to summer drought."

In Phylloglossum the prothallus is stated to be of the L.cernumm type, ${ }^{3}$ whilst the climatic conditions under which it grows are also those of a winter rainfall and a dry summer period. The gametophyte generation and the conditions of growth are thus similar to those of the protocorm-producing species of Lycopods. It is not surprising, then, that Phylloglossum should produce a protocorm, since this structure appears to be essentially of biological importance in the life-history of plants having a short-lived prothallus of the $L$ : cernumm type and growing under special climatic conditions. Many workers have regarded the tuber of Phylloglossum as a protocorm, but this is hardly a legitimate use of the term. By comparison with species of Lycopodium it will be recognized that it is the cell mass formed by regenerating leaves, and not the tuber which may arise from it, that must be considered as the protocorm, since it corresponds to the protocorm of Lycopodium spp. in developmental history and in function. Unfortunately the embryology of Phylloglossum is as yet imperfectly known, but such evidence as we have indicates that a swollen cell mass is formed before the initiation of the tuber. ${ }^{4}$ Miss Sampson has recently described a sporeling of Phylloglossum, and from her account ${ }^{5}$ it is obvious that there is both 'an embryonic swelling' and a tuber. Unfortunately the account was limited to a single specimen, and it could not be determined whether the embryonic swelling was epibasal in origin, corresponding with the protocorm of L. cernumm. This seems probable, and there can be little doubt that biologically it is similar, functioning as a primary storage structure.

In the tuber of Phylloglossum we have a different structure. It has repeatedly been emphasized that, in the process of vegetative reproduction, tuber and cell mass or protocorm are two structures, the former arising from the latter only if conditions be favourable for continued growth. Such meagre facts as we have of the embryology are capable of a similar interpretation. The tuber is something extra, a structure in which Pliylloglossum has 'bettered' the mode of life of certain species of Lycopods ${ }^{6}$ (e.g. L. inundatum, which annually dies off to the tip of its shoot), since a definite tuber is unknown in that genus. Borrowing a term from another branch of biological science, the tuber may be regarded as a character of considerable 'survival value', for the climatic and edaphic conditions under which Phylloglossum has been studied are severe; but it seems hardly legitimate to style the tuber of Phylloglossum a 'protocorm ' if any morphological value is to be retained for that term. That there is a distinction between these two organs is borne out to some extent by their differing

1 Holloway, J. E. (1915) : loc. cit., p. 276.

- Thomas, A. P. W. : loc. cit., p. 289.

Sampson, K. : loc, cit., p. 607.
2 Loc. cit., p. 263.

1 Thomas, A. P. W.: loc. cit., p. 288.

- Bower, F. O. (1914) : loc. cit., p. $56_{5}$. 
response to the stimulus of gravity. It has been pointed out that the new tuber is definitely geotropic. The adventitious tuber behaves similarly, but the cell mass or protocorm, which is developed first by the regenerating leaf, does not. It may grow from any side of the leaf in relation to the ground, and, even when developed in contact with it, shows no penetration into the soil beyond such amount as is due to expansion of the group of cells. The cell mass is a transitory structure and rarely attains any size, but where, as in Text-fig. I2, an unusually large one has formed, its growth is plagiotropic rather than geotropic.

It is not intended to discuss the morphology of the tuber at any length, but the following remarks may be deemed pertinent. In I 886 it was shown by Bower that the new tuber in sterile plants is formed directly from the apex of the plant, while in fertile plants, the apex of which develops the peduncle and cone, the new tuber is an adventitious growth bearing no relation to the leaf arrangement. This is substantially our position to-day, though recently Miss Sampson ${ }^{1}$ has on anatomical grounds attempted to show that in fertile plants the apex bifurcates and that the new tuber is of the nature of a branch. The vascular anatomy of a minute plant such as Phyiloglossum is subject to considerable variation, as was shown by Bower. ${ }^{2}$ The writer has hardly examined sufficient plants in serial section to be able to affirm or refute Miss Sampson's contention, but it seems significant that in two fertile plants recently studied no connexion existed between the vascular supply to the new tubers and the stele of the plant producing it. In one case, a four-leaved plant with two roots, the vascular strand from the new tuber completely died out in the stem before the xylem masses of the two roots coalesced, and far below the point to which any leaf trace penetrated. It is therefore hardly legitimate to assume that in all cases the tuber of fertile plants of Phylloglossum is a modified branch, or, indeed, that it represents 'a highly specialized leafy axis'. The 'vascular supply' to the adventitious tuber has been shown to be a late development and in no case connected with the tracheides in the regenerating leaf. The wide tracheidal cells of the 'vascular supply', with their loose spiral or reticulate lignification, resemble rather 'storage tracheides' than conducting elements. Such a function affords a reasonable explanation of the cup of tracheides formed at the distal-end of the stalk round the new tuber apex. The reproduction of tubers by detached leaves agreeing, even to details of vascular supply, with those formed normally by the plant in each growing season, suggests that caution is necessary before adopting a generalization as to the morphology of the tuber which is based entirely on anatomical evidence.

1 Sampson, K. (1916): Ann. Bot., $x \times x$, p. 331.

Bower, F. O. (1885) : loc. cit., p. 674, and Pl. 7o, Figs. 42, 43. 


\section{SUMMARY.}

1. Phylloglossum Drummondii occurs in South Australia as a member of the geophytic element in the flora of an area subject to prolonged summer desiccation.

2. The examination of a number of living plants has shown that, whilst the average depth of the current tuber is about I c.m., owing to various accidental causes it may range from a surface position to a depth of at least $2 \mathrm{~cm}$.

3. Whatever the depth of the current tuber, the growing plant tends to form its new tuber at an average depth of $1 \mathrm{~cm}$. This adjustment is effected by variation in length of the tuber stalk.

4. A new method of vegetative reproduction is described. for Phylloglossum. This consists in regeneration from leaves, injured or detached by accidental causes.

5. In regeneration there is first produced an adventitious cell mass, at or near the proximal end of the leaf and arising from the abaxial surface. This cell mass is regarded as the protocorm.

6. From a growing-point differentiated on the cell mass a tuber develops which resembles that formed by the normal plant.

7. Reasons are advanced for regarding the protocorm and tuber as two distinct and independent structures.

8. The results of the investigation emphasize the biological value of the tuber, and morphological interpretations, based on anatomical evidence only, should be accepted with caution.

I am greatly indebted to Professor W. H. Lang, F.R.S., for his kindness in seeing this paper through the press.

Botanical Department, UNIVERSITY OF ADELAIDE.

\section{LITERATURE CITED.}

Bower, F. O. (1885): On the Development and Morphology of Phylloglossum Drummondii. Phil. Trans. Roy. Soc., London, vol. clxxvi, pp. 665-78.

(1908) : The Origin of a Land Flora.

(1914): Address to the Botanical Section. Brit. Ass. Report, Australia, 1914, pp. 560-72.

GoEbel, K. (1900) : Organography of Plants. Part I. General Organography.

(1905): Organography of Plants. Part II. Special Organography.

Holloway, J. E. (1914): Preliminary Note-on the Protocorm of Lycopodium laterale, R. Br. Trans. and Proc. N.Z. Inst., vol. xlvii, pp. 73-5.

(1915): Studies in the New Zealand Species of Lycopodium. Part I. Ibid., vol. xlviii, pp. 253-303.

(1916): Studies in the New Zealand Species ot Lycopodium. Part II. Methods of Vegetative Reproduction. Ibid., vol. xlix, pp. 80-93. 


\subsection{Osborn.-Some. Observations on the Tuber of Phylloglossum.}

LANG, W. H. (1915): Address to the Botanical Section. Brit. Ass. Report, Manchester, 19I5, pp. $701-18$.

OSBORn, T. G. B. (1918): On the Habitat and Method of Occurrence in South Australin of Two Genera of Lycopods hitherto unrecorded for the State: Trans. Roy. Soc., S. Aus., vol. xlii, pp. I-I 2..

Robertson, A. (1906): The Droppers of Tulipa and Erythronium. Ann. Bot., vol. xx, pp. $4^{29}-4^{\circ}$.

Sampson, K. (1916) : The Morphology of Phylloglossum Drummondii, Kunze. Ann. Bot., vol. xxx, pp. 3I 4 -3I.

(1916): Note on a Sporeling of Phylloglossum attached to a Prothallus. Ibid., Pp. $605-7$.

Tromas, A. P. W. (1902) : Preliminary Account of the Prothallium of Phy'lloglossum, Proc. Roy. Soc., London, vol. 1xix; pp. $28_{5}-91$.

Wernfiam, H. F. (1910): The Morphology of Phylloglossum Diummondii. Ann. But., vol, xxiv, pp. $33 \mathbf{5}-4 i$.

\section{EXPLANATION OF PLATE XXVIII.}

Illustrating Mr. Osborn's paper on Some Observations on the Tuber of Phylloglossum.

\section{All figures $\times 20$.}

$c . m_{.}=$cell mass $; g . p .=$ growing-point $;$ t.s. $=$ tuber stalk; $v . b .=$ vascular bundle of detached leaf ; v.s. = 'vascular supply' in tuber stalk.

Photo I. Transverse section of leaf showing considerable cell mass. A growing-point has begun to differentiate.

Photo 2. Transverse section of leaf showing cell mass. The proliferation of individual epidermal cells is shown on left. Two growing-points are differentiating, and the cell mass between them shows a continuous anticlinal wall for several cell rows. Some rhizoids $\left(r . h_{\text {. }}\right)$ have developed on left side.

Photo 3. Iongitudinal section (somewhat oblique) of leaf found in field (Text-fig. 10), showing differentiation of growing-point on cell mass. The greater part of this is of epidermal origin, but secondary divisions bave occurred in two mesophyll layers.

Photo 4. Longitudinal section of leaf, showing large cell mass and unusually marked secondary development in mesophyll. Note the injured surface of this leaf is oblique.

Photo 5. Longitudinal section of leaf with small cell mass and stalk of tuber. The essentially epidermal origin of the adventitions structure formed in regeneration is seen.

Photo 6. Transverse section of leal with irregularly lobed cell mass. The larger lobe has formed a growing-point which has invaginated and lies at the base of a short pit, the channel.

Photo 7. Longitudinal section of leaf and adventitious tuber after three months' growth. The tuber has swollen and the growing-point is situated in a chamter at the upper pole. The tuber as yet shows no differentiation, nor is there any 'vascular supply' in the stalk.

Photo 8. Transverse section of leaf bearing adventiticus tuber, which is nearly fully developed. Storage tissue, tuber coat, and growing:point are all visible, and rhizoids are present on the tuber and stalk.

Photo 9. Longitudinal section of leaf and adventitious tuber at about the same stage as that in Photo 8. The bend on the tuter stalk is accidental.

Photo io. Somewhat tangential section of same leaf as Photo 9, showing 'tracheides' of ' vascular supply' in the cell mass, and tuber stalk, with expansion at the distal end of the latter. The opening of the channel to the exterior (o.c.) is seen.

Photo II. - Longitudinal section of adventitious growth from detached leaf (Text-fig. 20) with tuber coat, bearing rhizoids, storage tissue, and growing-point. The 'leaflet' $(l$.) is seen passing out of the plane of the section on left.

Photo 12. Transverse section of leaf (Text-fig. 25) bearing many cell masses, one of which is becoming tuberous (t.b.) directly, without foiming a definite apex. 


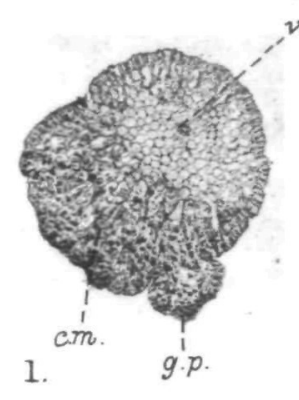

v. 6.
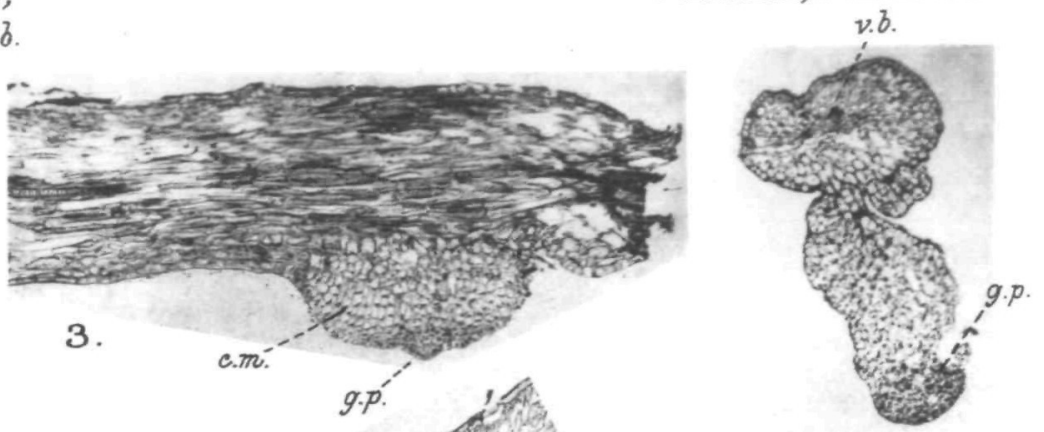

6.
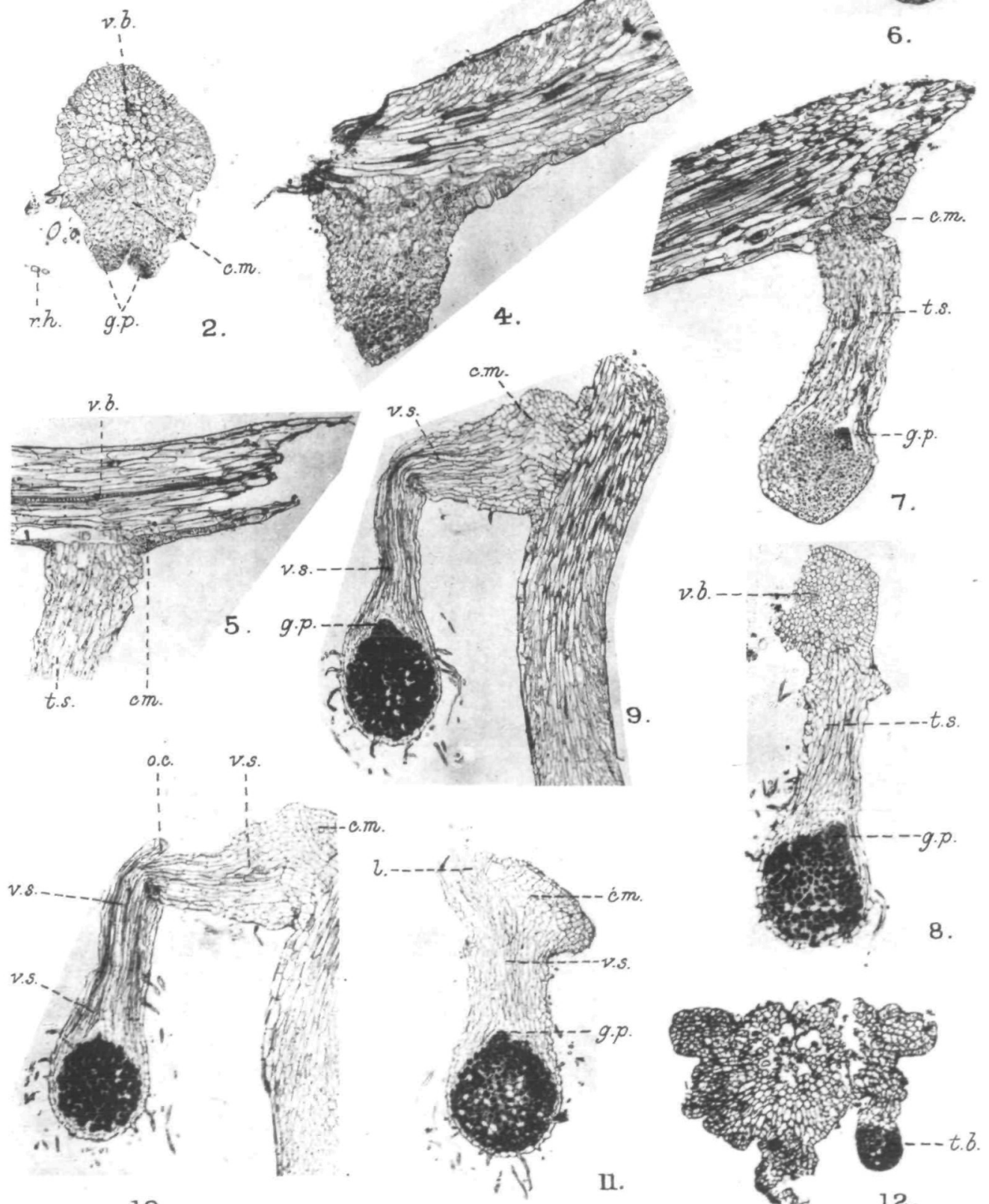

10.
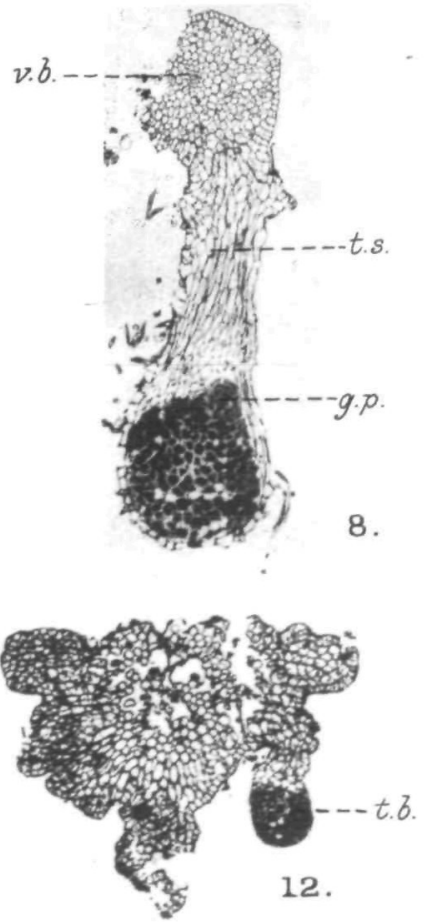
Downloaded from https://academic.oup.com/aob/article-abstract/os-33/4/485/214607 by Durham University user

on 25 March 2018 